\title{
Application of BiOX Photocatalysts in Remediation of Persistent Organic Pollutants
}

\author{
Robert B. Arthur ${ }^{1}$, John C. Ahern ${ }^{1,2}$ and Howard H. Patterson ${ }^{1, *}$ \\ 1 Department of Chemistry, University of Maine, Orono, ME 04469, USA; robert.arthur@maine.edu (R.B.A.); \\ johncoryahern@msn.com (J.C.A.) \\ 2 Materials Recovery \& Recycle Group (AMPP-4) Actinide Materials Processing \& Power Division, \\ Los Alamos National Laboratory, Los Alamos, NM 87545, USA \\ * Correspondence: howardp@maine.edu; Tel.: +1-207-581-1178
}

Received: 31 October 2018; Accepted: 28 November 2018; Published: 2 December 2018

check for updates

\begin{abstract}
Bismuth oxyhalides have recently gained attention for their promise as photocatalysts. Due to their layered structure, these materials present fascinating and highly desirable physicochemical properties including visible light photocatalytic capability and improved charge separation. While bismuth oxyhalides have been rigorously evaluated for the photocatalytic degradation of dyes and many synthesis strategies have been employed to enhance this property, relatively little work has been done to test them against pharmaceuticals and pesticides. These persistent organic pollutants are identified as emerging concerns by the EPA and effective strategies must be developed to combat them. Here, we review recent work directed at characterizing the nature of the interactions between bismuth oxyhalides and persistent organic pollutants using techniques including LC-MS/MS for the determination of photocatalytic degradation intermediates and radical scavenging to determine active species during photocatalytic degradation. The reported investigations indicate that the high activity of bismuth oxyhalides for the breakdown of persistent organic pollutants from water can be largely attributed to the strong oxidizing power of electron holes in the valence band. Unlike conventional catalysts like $\mathrm{TiO}_{2}$, these catalysts can also function in ambient solar conditions. This suggests a much wider potential use for these materials as green catalysts for industrial photocatalytic transformation, particularly in flow chemistry applications.
\end{abstract}

Keywords: photocatalysis; BiOX; LC-MS/MS; persistent organic pollutants

\section{Introduction}

As a result of modern industrial development, nearly 9000 compounds are currently in use worldwide for pharmaceutical applications [1]. In addition to pharmaceuticals, many other biologically active chemicals including Persistent Organic Pollutants (POPs) have well-established routes of entry to water supplies and can cause long-term contamination [2-5]. Since these molecules do not interact appreciably with water, their rate of hydrolysis and subsequent removal proceeds very slowly, meaning that these compounds have long half-lives and will slowly build up in water supplies [6,7].

Current wastewater treatment processes have been shown to be insufficient in removing POPs from drinking water [2]. Additionally, traditional techniques such as chlorination, while efficient at removing bacteria, have shown the potential to chemically generate more toxic versions of POPs including trihalomethanes [8]. Alternative options to traditional methods must be explored to combat this emerging issue. Photocatalysis was first demonstrated by Fujishimi and Honda in 1972 where they showed that irradiating single crystal rutile titanium dioxide $\left(\mathrm{TiO}_{2}\right)$ with ultraviolet light enabled the production of $\mathrm{H}_{2}$ and $\mathrm{O}_{2}$ via photolysis of water [9]. This landmark study was followed in 1976 by Carey et al., who showed that aqueous suspensions of $\mathrm{TiO}_{2}$ in the presence of organic pollutants was 
able to photocatalytically degrade the organic compounds [10]. These studies have sparked intense interest in the development of photocatalysts for environmental remediation applications.

Heterogeneous photocatalytic semiconductors work by absorbing light of an appropriate wavelength to promote electrons from its valence band to its conduction band. This process generates excited electrons in the conduction band and effective "electron holes" in the valence band. The electron-hole pairs are then able to move to the surface of the semiconductor where reactions can occur, or thermally recombine. Recombination is detrimental to the overall activity of a catalytic system since recombined electron-hole pairs are not able to participate in the intended reaction. The surface reactions that take place in semiconductor photocatalysis consist of either oxidation by electron holes in the valence band, or reduction by excited electrons in the conduction band.

$\mathrm{TiO}_{2}$ has received the most attention in photocatalysis research as it was the first photocatalyst discovered and is still one of the most widely-utilized materials [9]. $\mathrm{TiO}_{2}$ has been applied in such diverse applications as self-cleaning surfaces and dye-sensitized solar cells [11]. However, $\mathrm{TiO}_{2}$ has the drawback of possessing a large band gap of $3.2 \mathrm{eV}$ which prevents it from being applied in solar photocatalytic applications [12]. Using ambient solar light in an outdoor treatment facility can reduce the cost of photocatalysis-based water treatment vs. using lamps over tanks at a typical indoor water treatment plant. Various strategies have been employed to develop robust photocatalysts capable of functioning under ambient solar light. Investigators have tried to imbue visible-light activity to $\mathrm{TiO}_{2}$, including metal and non-metal doping including nanoparticles and heterojunction formation [13-15]. However, these systems are inherently more complicated to synthesize and more expensive to produce [13-15]. A novel semiconductor system is required that is capable of utilizing visible light, while also maintaining low rates of recombination. Bismuth oxyhalides are an alternative to $\mathrm{TiO}_{2}$ with high photocatalytic degradation rates for organic compounds in water and potential functionality in ambient conditions [12].

In this review, the unique properties of BiOX compounds that allow for their high photocatalytic activity are discussed in detail. Previous research focusing on synthesis strategies and applications of $\mathrm{BiOX}$ as photocatalysts with elucidation of structure-activity relationships is briefly summarized. Finally, we focus on recent applications of BiOX to the degradation of persistent organic pollutants and implications of the mechanistic aspects of these reactions for both photocatalytic degradation.

\section{Properties of Bismuth Oxyhalide Compounds and Development of Their Use as Photocatalysts for Water Remediation}

Compounds of the bismuth oxyhalide series (BiOX) exhibit interesting optical and semiconducting properties. The tetragonal structure of BiOX was first determined by Bannister in 1935 [16] and consists of covalently bonded layers of [X-Bi-O-Bi-X]. These layers are stacked on top of each other and are held together by Van der Waals interactions between the halides. This structure results in the presence of an internal electric field which can be modulated by carefully controlling which facets of the crystal are exposed. The general crystal structure for BiOX is given in Figure 1. 


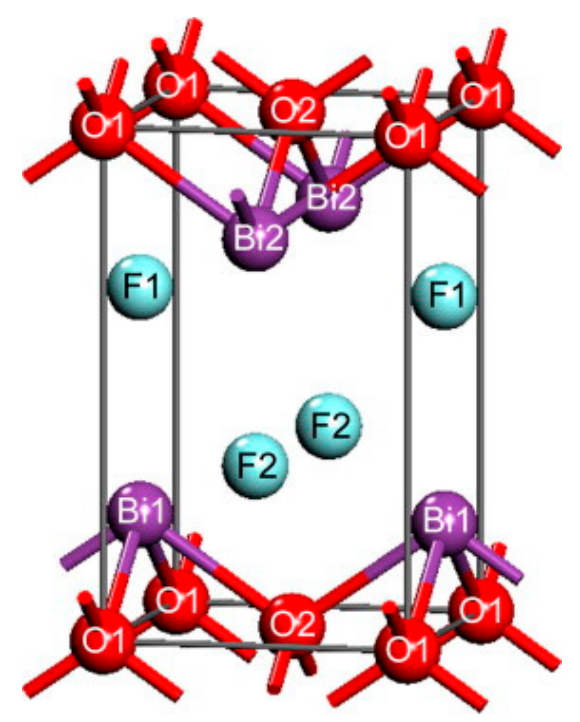

Figure 1. Computer-generated model of BiOX structure. Reused with permission from reference [17]. Copyright Elsevier 2008.

Bismuth oxychloride $(\mathrm{BiOCl})$ was the first $\mathrm{BiOX}$ compound to be tested for photocatalytic properties by Zhang et al. in 2006 [18]. After this initial study, many other reports have followed further establishing the capabilities and potential of BiOX compounds as photocatalysts. Many researchers have undertaken attempts to improve the photocatalytic activity of BiOX compounds in order to enable their use in industrial applications. Two primary approaches have been undertaken toward this goal: (1) the development of synthetic methods directed at novel BiOX structures, and (2) the modulation of BiOX using various dopants. Since the properties of a material are derived from structure, synthetic methods such as crystal facet engineering [19-32], production of ultrathin nanosheets [33-35], and synthesizing hollow and porous nanostructures [36-42] have been developed to access novel morphologies. Doping strategies include metal-doping [43-48], nonmetal-doping [49,50], introduction of structural defects $[25,26,31,51-54]$, use of dye-sensitizers [55,56], and inclusion in heterojunctions with other semiconductors $[47,48,54,57-67]$. For in-depth discussion of the diverse approaches to BiOX synthesis see reviews by Di et al. [68] and Yang et al. [69].

Bismuth oxyhalide compounds are not as widely used in industry as $\mathrm{TiO}_{2}$. While $\mathrm{BiOX}$ compounds are relatively affordable [12]. BiOX compounds can become the preferred option of photocatalytic degradation of water-borne organic contaminants. This is due largely to the fact bismuth oxyhalide compounds such as $\mathrm{BiOI}\left(\mathrm{E}_{\mathrm{g}}=1.7 \mathrm{eV}\right)$ possess narrow bandgaps compared to $\mathrm{TiO}_{2}\left(\mathrm{E}_{\mathrm{g}}=3.2 \mathrm{eV}\right)[12]$ and therefore can function under lower-energy irradiation including visible light $[12,70]$. Numerous other groups have also shown BiOX catalysts present high photocatalytic activity under visible light irradiation [71-74]. This is a tremendous advantage of using BiOX catalysts since water can be treated in outdoor facilities vs. storing it in tanks or channels at a wastewater treatment facility with continuously running UV lights. Being able to treat water with ambient sunlight reduces logistical difficulties with treating the water and saves the cost of additional wastewater treatment plant space and electricity for operating UV lamps.

BiOX photocatalysts have been previously used in applications including water splitting $[19,62,65]$, solar cells [75], photoreduction of $\mathrm{CO}_{2}[21,31,76], \mathrm{N}_{2}$ fixation [77,78], bacterial disinfection [79], removal of air contaminants [80-84], oxidation of heavy metal pollutants [85-90], and photodynamic therapy [44]. As mentioned in the introduction, this review will highlight studies of BiOX photocatalytic degradation of persistent organic pollutants. Previous studies on application of BiOX to the degradation of organic pollutants have focused on pollutants such as dyes, pharmaceuticals, and industrial effluents $[47,53,58,91-97]$. The primary active species responsible for the high photocatalytic degradation properties of BiOX have been identified to be electron holes and superoxide 
radicals $[47,95,96]$. However, the mechanism of photocatalytic degradation of persistent organic pollutants have not been studied in detail. The following sections will particularly focus on the mechanisms through which $\mathrm{BiOX}$ reacts directly with pollutants to break them down.

\section{Characterization of BiOX Compounds Used for the Photocatalytic Degradation of Water-Borne Endocrine Disrupting Compounds}

Patterson et al. previously reported the use of BiOX catalysts for the photocatalysis of synthetic estrogen $17 \alpha$-ethinyl estradiol (EE2) and the estrogen estriol in water [12]. This was the first report of photodecomposition of estrogenic materials using such catalysts. The BiOX catalysts exhibited greater photodecomposition of the chosen POPs than the tested $\mathrm{TiO}_{2}$ alternative here.

EE2 and estriol were chosen as model endocrine disrupting compounds (EDCs). EE2 was chosen since it is used by millions of women as a contraceptive every day in the U.S. alone [98]. EE2 and other synthetic estrogens are designed to mimic natural estrogens and are able to bind to estrogen receptors. EDCs such as EE2 have an adverse effect on organisms at even low concentrations [98,99]. Aquatic species including fish and amphibians are especially at risk to such EDCs, in part because these compounds bioaccumulate in tissues and biomagnify up the food chain [99-101]. Food chains for aquatic environments tend to have more trophic levels than their terrestrial counterparts, so there is more opportunity for biomagnification of pollutants in aquatic environments. The problem is compounded further since these compounds and their metabolites are persistent enough in waterways to survive transport across thousands of miles and can be detected in nearly any major waterway [102-105]. Certain aquatic species can experience infertility after exposure to ng-level doses of EE2 [98]. EE2 and related EDCs have been identified as contaminants of emerging concern by the EPA and other environmental protection agencies [98,106-111].

The $\mathrm{BiOCl}$ and $\mathrm{BiOI}$ catalysts were compared against $\mathrm{TiO}_{2}$ by dispersing each catalyst type in separate quartz flasks filled with $\mathrm{mg} / \mathrm{L}$ EDC-doped deionized water under continuous stirring [12]. These flasks were placed one-at-a-time in a chamber ringed with either $254 \mathrm{~nm}$ or $350 \mathrm{~nm}$ bulbs. Aliquots were taken from the flasks at given time intervals. These aliquots were each examined via luminescence spectroscopy and LC-MS/MS for EDC concentration. Catalysts were ranked based on the concentration of EDC remaining in the tested aliquots, where the less EDC there was left, the better the photocatalyst. BiOI was the most effective catalyst tested using the $350 \mathrm{~nm}$ light source and $\mathrm{BiOCl}$ was the preferred catalyst using the $254 \mathrm{~nm}$ light source. The difference between BiOX and $\mathrm{TiO}_{2}$ in degrading EE2 and estriol was most pronounced when using a lower-energy light source (350 $\mathrm{nm}$ ) as seen in Table 1 and Figure 2. This lends credence to the idea that these catalysts can function in natural-light conditions where much of the spectrum is in the visible or low-energy UV range. Using a catalyst capable of working in natural solar-light can reduce the cost of pollution remediation in wastewater treatment facilities since the water can be treated in outdoor facilities versus being processed in tanks with UV lamps.

Table 1. Percent of EE2 remaining in solution after treatment with different catalysts and $350 \mathrm{~nm}$ light as determined via luminescence spectroscopy. Initial concentration of EE2 was $10.000 \mathrm{mg} / \mathrm{L}$. Experiments were conducted three times and the results were averaged to generate the table below. Reused with permission from reference [12]. Copyright Elsevier 2015.

\begin{tabular}{ccccc}
\hline Catalyst & 0 min UV (Pre-Ads.) & 0 min UV (Post Ads.) & 20 min UV & 30 min UV \\
\hline $\mathrm{BiOCl}$ & 100 & 46.0 & 18.9 & 0 * \\
$\mathrm{BiOI}$ & 100 & 38.1 & 0.607 & 0 * \\
$\mathrm{TiO}_{2}$ & 100 & 68.1 & 28.7 & 3.85 \\
$\mathrm{No}$ catalyst & 100 & 100 & 84.1 & 82.4 \\
\hline
\end{tabular}

\footnotetext{
* Signal intensity was zero but the concentrations could not be discriminated below $7.00 \mu \mathrm{g} / \mathrm{L}$.
} 


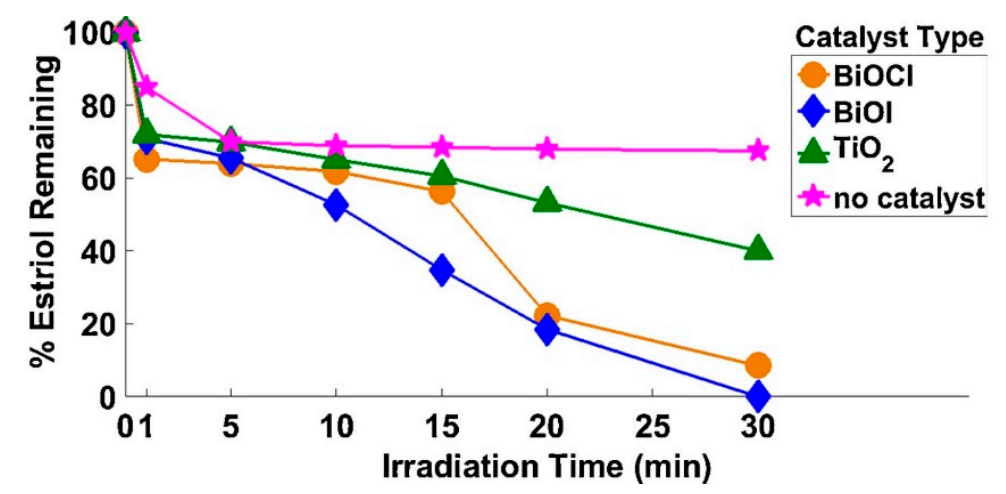

Figure 2. Percent estriol remaining in solution vs. time for estriol in the presence of catalysts under $350 \mathrm{~nm}$ light. The readings at time zero do not account for adsorption before exposure to the light source. Reused with permission from reference [12]. Copyright Elsevier 2015.

Ionized fragments identified by LC-MS/MS were also used to derive mechanisms for degradation of both EE2 and estriol as pictured in Figure 3. There was no apparent difference in mechanism based on catalyst type [12].

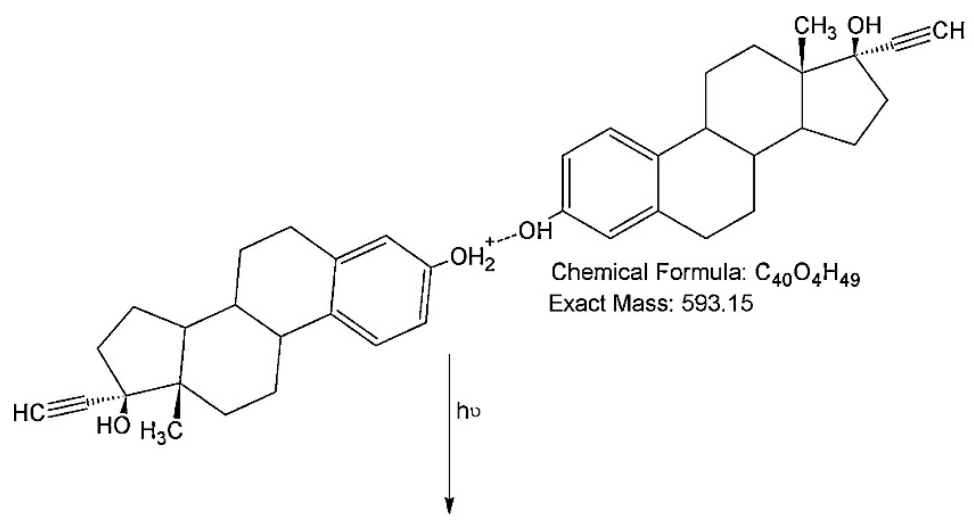<smiles>CC1(O)CCC2C3CCc4cc(O)ccc4C3CCC2(C)C1[14C](=O)[O-]</smiles><smiles>C#CC1(O)CCC2C3CCc4ccccc4C3CCC21C</smiles>

Chemical Formula: $\mathrm{C}_{20} \mathrm{H}_{23} \mathrm{O}$ Exact Mass: 297.403

Chemical Formula: $\mathrm{C}_{10} \mathrm{H}_{15} \mathrm{O}$ Exact Mass: 153.08<smiles>C[C@]12CCCC[CH+]1CCC2O</smiles><smiles>CCCCCCCC</smiles><smiles>CC1CCC[C@]2(C)C1CC[C@@H]2O</smiles>

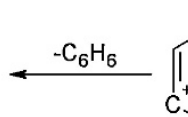
Exact Mass: 279.16<smiles>OC1CCCC1</smiles>

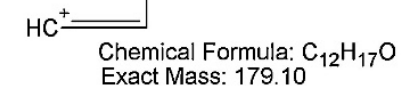
Exact Mass: 179.10

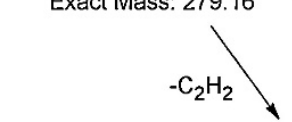<smiles>CCCC1CCCC2(C)C(O)CCC12</smiles>

Chemical Formula: $\mathrm{C}_{18} \mathrm{H}_{23} \mathrm{O}$ Exact Mass: 253.12

Chemical Formula: $\mathrm{C}_{6} \mathrm{H}_{11} \mathrm{O}$

Exact Mass: 99.03

Figure 3. Mechanism for degradation of EE2 given $350 \mathrm{~nm}$ exposure. Reused with permission from reference [12]. Copyright Elsevier 2015. 
The catalysts were tested for re-use capability and showed effective degradation of the EDCs for at least 8 uses without any post-treatment. This reusability is superior to $\mathrm{TiO}_{2}$-based catalysts which could only be used twice before fouling of the surface rendered the $\mathrm{TiO}_{2}$ ineffective. The useful lifespan of the BiOX catalysts could be further increased if the fouling was removed from the catalyst surfaces by recycling methods such as washing and/or heat treatment. The catalysts were also tested for their physical and photophysical properties via scanning Electron Microscopy Energy Dispersive X-ray Spectroscopy (SEM-EDS), X-ray Diffraction (XRD), Brunauer Emmet Teller (BET) analysis and Dynamic Light Scattering Spectroscopy (DLS). Figure 4 shows the SEM images of the BiOCl and BiOI catalysts. The EDS results confirmed the elemental compositions of the samples as $\mathrm{BiOCl}$ and BiOI. The narrow peaks in the XRD spectra of Figure 5 indicate a single phase and were in agreement with previously published works on BiOX compounds [112,113]. BET analysis revealed that the BiOX catalysts had lower surface area than $\mathrm{TiO}_{2}$ as pictured in Table 2 . The higher photocatalytic activity of the BiOX catalysts despite their lower surface area lends credence to the argument that the lower band gap of the $\mathrm{BiOX}$ catalysts allows for superior activity vs. $\mathrm{TiO}_{2}$, especially given the lower-energy $350 \mathrm{~nm}$ irradiation. DLS analysis showed no significant difference in particle size distribution before vs. after UV exposure.

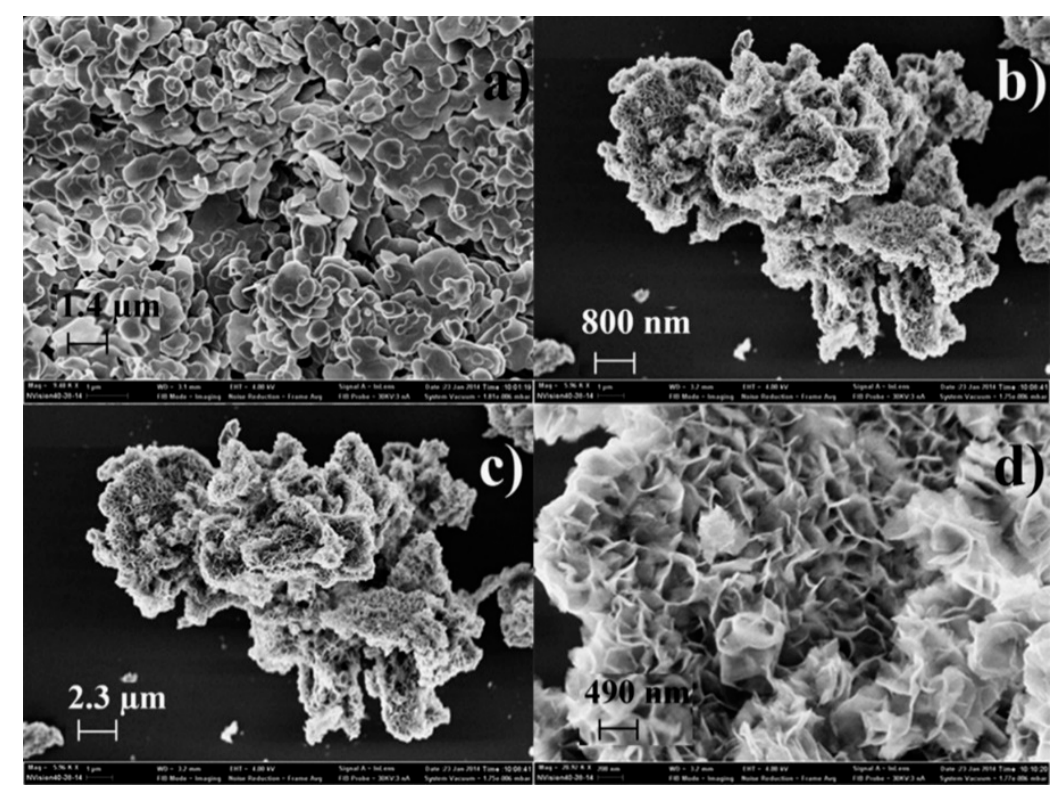

Figure 4. SEM images of (a) BiOCl platelet clusters at $9.48 \mathrm{e}^{3}$ magnification. (b) Single BiOCl cluster at $16.6 \mathrm{e}^{3}$ magnification. (c) BiOI platelet clusters at $5.96 \mathrm{e}^{3}$ magnification. (d) Single BiOI cluster at $28.9 \mathrm{e}^{3}$ magnification. Reused with permission from reference [12]. Copyright Elsevier 2015.

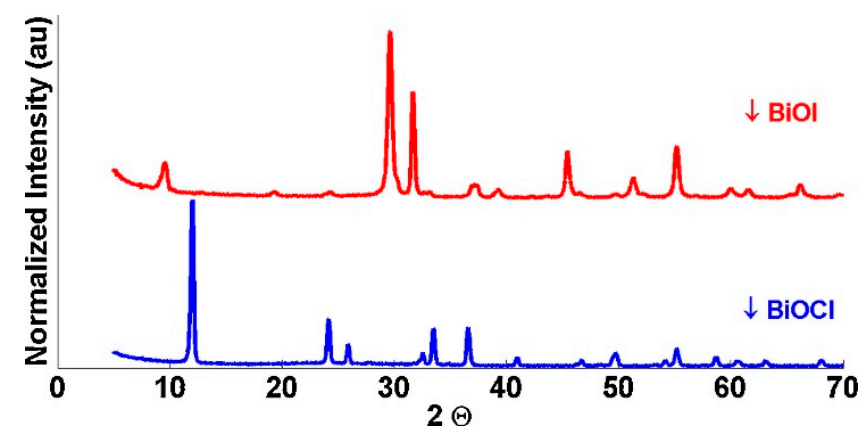

Figure 5. XRD spectra for $\mathrm{BiOI}$ and $\mathrm{BiOCl}$. Reused with permission from reference [12]. Copyright Elsevier 2015. 
Table 2. Properties of Various Catalysts. Reused with permission from reference [12]. Copyright Elsevier 2015.

\begin{tabular}{cc}
\hline Catalyst Type & Surface Area \\
\hline $\mathrm{BiOCl}$ & 2.677 \\
$\mathrm{BiOI}$ & 11.07 \\
$\mathrm{TiO}_{2}$ & 50.00 \\
\hline
\end{tabular}

Solid-state luminescence provided further evidence of photoactivation in the UV range similar to the lamps used in the photocatalysis chamber as seen in Figures 6 and 7. The excitation peaks were matched with their corresponding emission peaks as indicated by the arrow annotations above the spectra. The BiOI had a single excitation peak at $381 \mathrm{~nm}$ corresponding with a broad emission band centered at $419 \mathrm{~nm}$. The $\mathrm{BiOCl}$ had an emission peak at $422 \mathrm{~nm}$ and another at $456 \mathrm{~nm}$ corresponding with excitations of $344 \mathrm{~nm}$ and $360 \mathrm{~nm}$, respectively [32,114]. These electronic transitions for both $\mathrm{BiOX}$ catalysts are thought to be from photo-excitation of the lattice and subsequent relaxation via phonon-phonon interactions resulting in the observed emissions $[32,114]$. These solid-state studies support the notion that electron holes are generated by the photo-excited Bi. These electron holes can then degrade the organics directly or react with $\mathrm{OH}^{-}$or $\mathrm{O}_{2}$ in aqueous solution to form highly reactive radicals which can likewise degrade the organics [115].

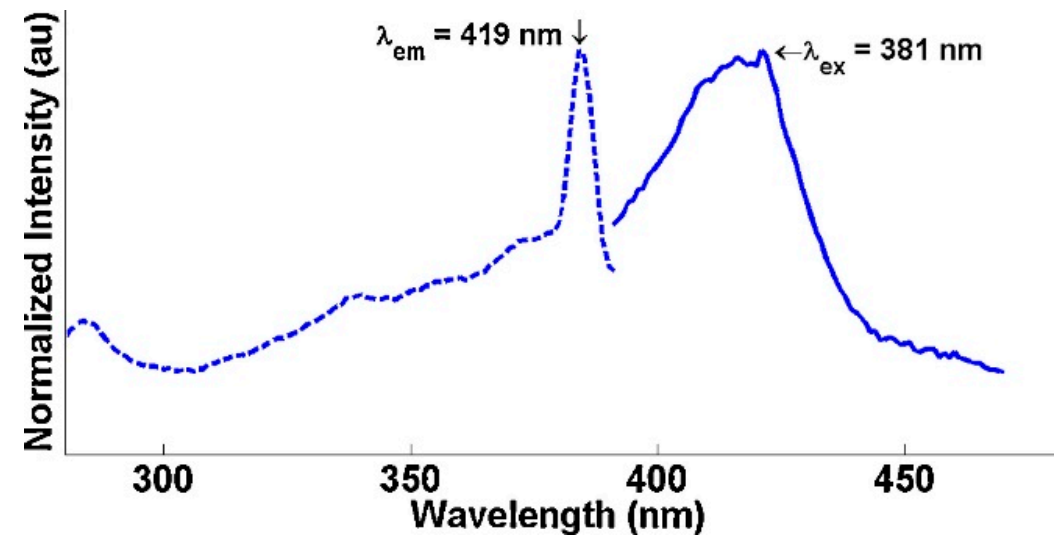

Figure 6. Solid-state luminescence spectra for BiOI at $77 \mathrm{~K}$. The excitation peak is matched with its corresponding emission peak as indicated by the arrows. Reused with permission from reference [12]. Copyright Elsevier 2015.

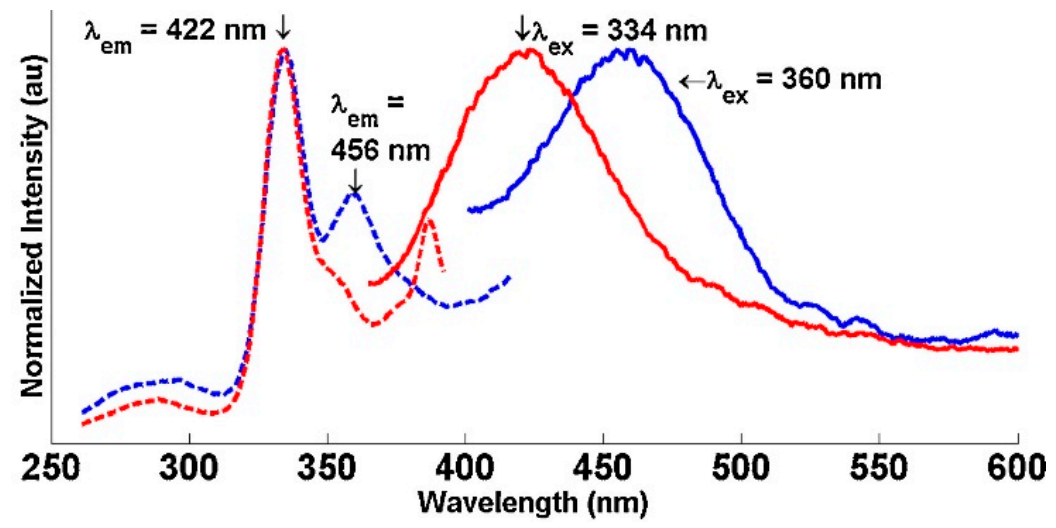

Figure 7. Solid-state luminescence spectra for $\mathrm{BiOCl}$ at $77 \mathrm{~K}$. The excitation peaks are is matched with their corresponding emission peaks as indicated by the arrows. Reused with permission from reference [12]. Copyright Elsevier 2015. 


\section{Investigation of BiOX-Based Catalysts for Degradation of Phenolic Compounds under Visible Light Conditions}

One of the major advantages of BiOX and select other bismuth-based catalysts are their narrow bandgaps relative to $\mathrm{TiO}_{2}[12,54,116]$. Sun et al. recently reported the visible-light degradation of phenolic compounds using bismuth oxybromide/oxyiodide compounds of the form $\left(\mathrm{Bi}_{4} \mathrm{O}_{5} \mathrm{Br}_{x} \mathrm{I}_{2-\mathrm{x}}\right)$ [116]. The photocatalytic degradation mechanism of resorcinol under these conditions was further investigated through radical trapping experiments as well as via identification of intermediates by LC-MS analysis. The activity of these catalysts in visible light conditions shows potential for BiOX-based catalysts to be used as commercial photocatalysts.

These catalysts were easily synthesized by adding $\mathrm{Bi}\left(\mathrm{NO}_{3}\right)_{3} \cdot 5 \mathrm{H}_{2} \mathrm{O}$ to a solution of ethylene glycol and then adding different ratios of $\mathrm{KBr}$ and $\mathrm{KI}$ [116]. The solution was then combined with an ammonia solution and the solid catalysts were allowed to precipitate out. The surface chemical composition and state were confirmed via SEM-EDS and X-ray photoelectron spectroscopy (XPS) [116]. The catalysts were confirmed to be of a single phase via XRD [116]. The catalysts were then separated from the solution and dried at $80^{\circ} \mathrm{C}$. UV-Vis diffuse reflectance spectroscopy (DRS) conducted on these catalysts showed that the band gap could be tuned based on the Br:I ratio [116]. In general, the band absorption edge of $\mathrm{Bi}_{4} \mathrm{O}_{5} \mathrm{Br}_{\mathrm{x}} \mathrm{I}_{2-\mathrm{x}}$ samples redshifted as $x$ decreased, with $\mathrm{Bi}_{4} \mathrm{O}_{5} \mathrm{I}_{2}$ absorption extending to 560 $\mathrm{nm}$. This indicates the visible-light-active photocatalytic potential of these materials. The collected DRS spectra and calculated band-gap energies are shown in Figure 8A,B respectively. The bandgap energies were calculated using the following formula: $\alpha h v=\mathrm{A}(h v-\mathrm{Eg})^{\mathrm{n} / 2}$ where $\mathrm{A}=$ absorbance and $\mathrm{n}=4[116]$.
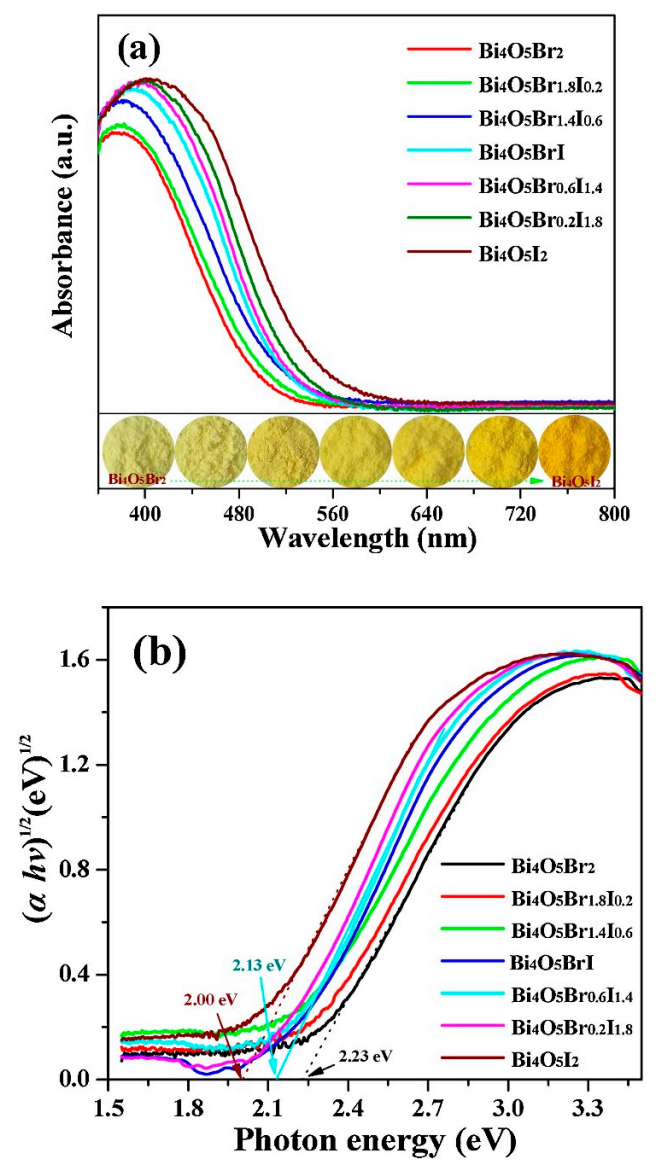

Figure 8. (a) Diffuse reflectance spectroscopy (DRS) spectra of $\mathrm{Bi}_{4} \mathrm{O}_{5} \mathrm{Br}_{\mathrm{x}} \mathrm{I}_{2-\mathrm{x}}, \mathrm{Bi}_{4} \mathrm{O}_{5} \mathrm{I}_{2}$ and $\mathrm{Bi}_{4} \mathrm{O}_{5} \mathrm{Br}_{2}$, (b) Graph of $(\alpha h v)^{1 / 2}$ vs. (hv) [116] Copyright Elsevier 2018. 
The photocatalytic potential under visible light for these catalysts was evaluated by exposing them to an aqueous solution of $30 \mathrm{mg} / \mathrm{L}$ phenolic compounds under a $500 \mathrm{~W}$ halogen lamp with a filter that cut-off wavelengths below $420 \mathrm{~nm}$. The catalyst $\mathrm{Bi}_{4} \mathrm{O}_{5} \mathrm{Br}_{0.6} \mathrm{I}_{1.4}$ was the most effective at degrading the selected phenolic compounds including resorcinol, o-phenylphenol (OPP) and 4-tert-butylphenol (PTBP) [116]. These trials established the high degradation potential for phenolic pollutants under these conditions and the results are summarized in Figure 9. The reusability of $\mathrm{Bi}_{4} \mathrm{O}_{5} \mathrm{Br}_{0.6} \mathrm{I}_{1.4}$ was studied over four trials and minimal loss in photocatalytic activity was observed (Figure 10A) [116]. This indicates that the degradation of phenolic pollutants under visible light by $\mathrm{Bi}_{4} \mathrm{O}_{5} \mathrm{Br}_{0.6} \mathrm{I}_{1.4}$ does not deactivate the photocatalyst. Further analysis of $\mathrm{Bi}_{4} \mathrm{O}_{5} \mathrm{Br}_{0.6} \mathrm{I}_{1.4}$ using XRD before and after exposure to phenolic pollutants and visible light revealed no observable changes in the structure (Figure 10B) [116].
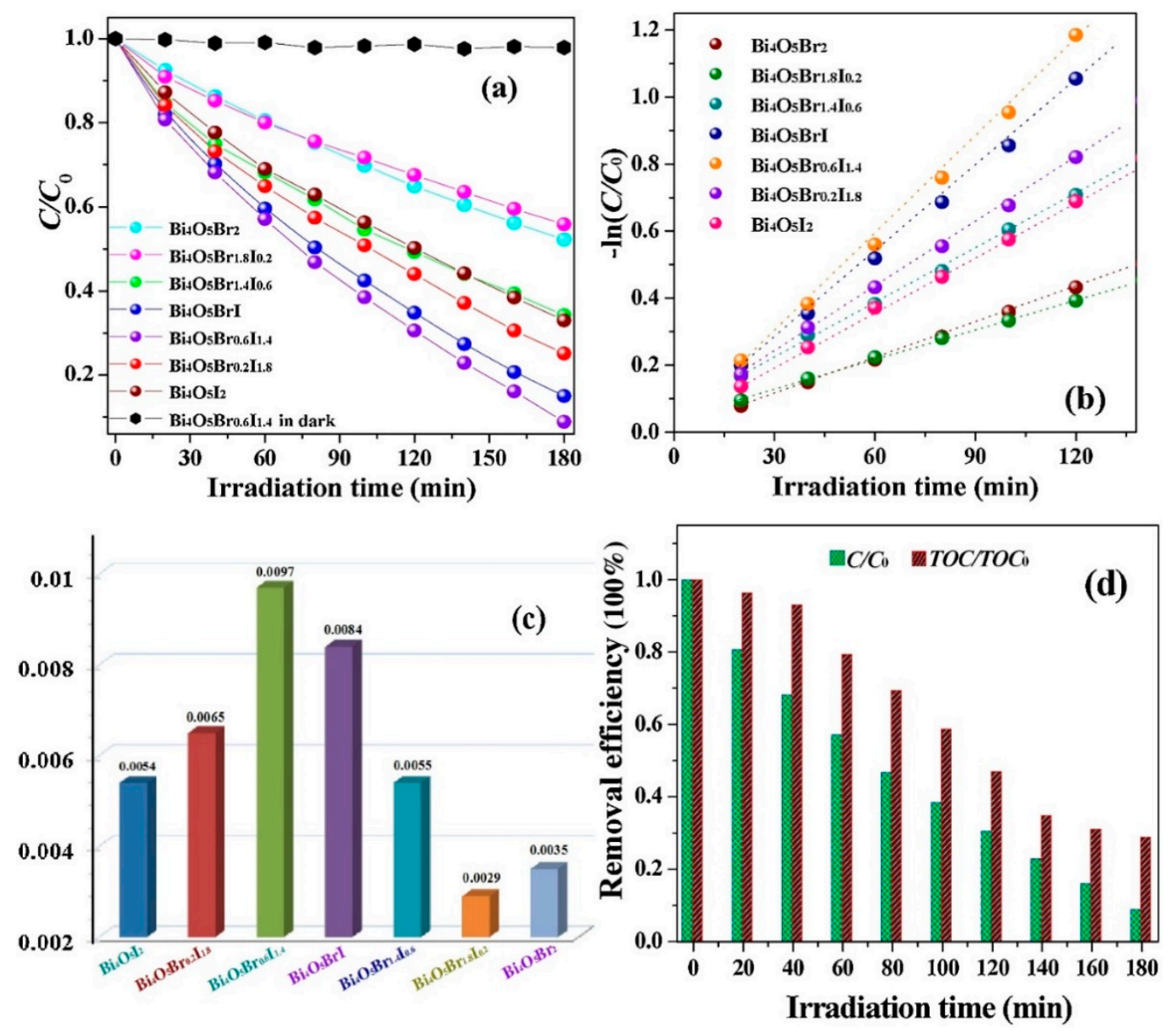

Figure 9. (a) Normalized zeroth-order degradation plot for $30 \mathrm{mg} / \mathrm{L}$ resorcinol treated with $\mathrm{Bi}_{4} \mathrm{O}_{5} \mathrm{I}_{2}$, $\mathrm{Bi}_{4} \mathrm{O}_{5} \mathrm{Br}_{2}$, and $\mathrm{Bi}_{4} \mathrm{O}_{5} \mathrm{Br}_{\mathrm{x}} \mathrm{I}_{2-\mathrm{x}}$ under visible light. (b) 1st order degradation plot for the degradation of resorcinol using additional catalysts. (c) Degradation constants calculated for resorcinol given treatment with various catalysts. (d) Plot of TOC vs. irradiation time for $30 \mathrm{mg} / \mathrm{L}$ solutions of resorcinol with $\mathrm{Bi}_{4} \mathrm{O}_{5} \mathrm{Br}_{0.6} \mathrm{I}_{1.4}$ [116]. Copyright Elsevier 2018. 
(a)

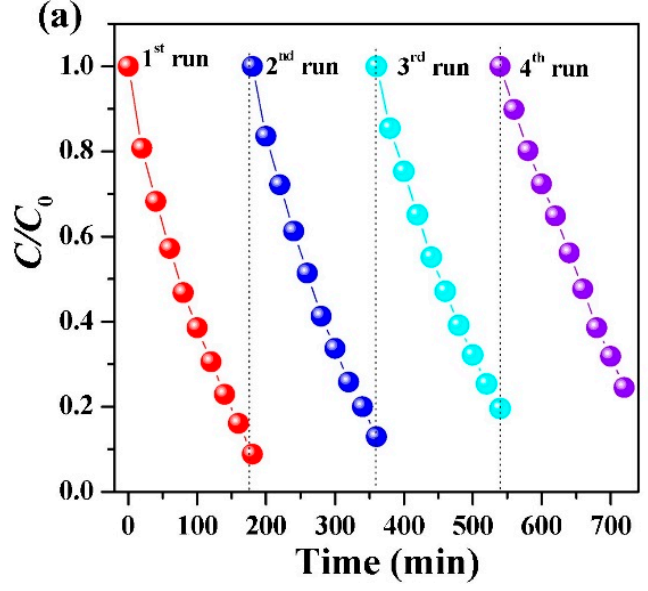

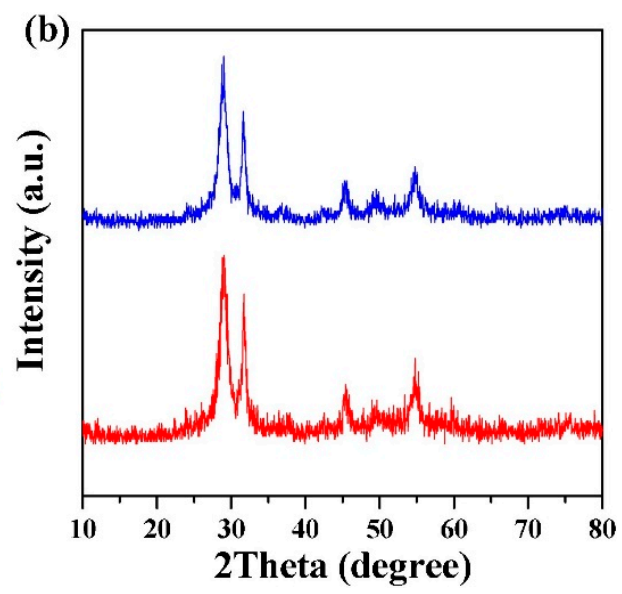

Figure 10. (a) Evaluation of recyclability of the catalyst via normalized zero-order degradation plot for resorcinol using recycled $\mathrm{Bi}_{4} \mathrm{O}_{5} \mathrm{Br}_{0.6} \mathrm{I}_{1.4}$. (b) XRD spectra of $\mathrm{Bi}_{4} \mathrm{O}_{5} \mathrm{Br}_{0.6} \mathrm{I}_{1.4}$. before (blue) and after (red) exposure to the visible light source and resorcinol solution [116]. Copyright 2018 Elsevier.

After initial experiments directed at characterizing the synthesized $\mathrm{Bi}_{4} \mathrm{O}_{5} \mathrm{Br}_{x} \mathrm{I}_{2-x}$ samples and their potential for visible light photocatalytic activity, the researchers turned their attention toward investigating the pathways responsible for the degradation of resorcinol. The band potentials for $\mathrm{Bi}_{4} \mathrm{O}_{5} \mathrm{Br}_{0.6} \mathrm{I}_{1.4}$ were first calculated using the Mott-Schottky equation. The calculated values suggest that the conduction band potential $\left(\mathrm{E}_{\mathrm{CB}}=-0.64 \mathrm{eV}\right)$ is sufficient to activate molecular $\mathrm{O}_{2}$, while the valence band potential $\left(\mathrm{E}_{\mathrm{VB}}=1.49 \mathrm{eV}\right)$ is not expected to be able to generate hydroxyl radicals [116]. This information was used to propose the photocatalytic mechanism for $\mathrm{Bi}_{4} \mathrm{O}_{5} \mathrm{Br}_{0.6} \mathrm{I}_{1.4}$ and is shown in Figure 11. Radical scavenging experiments were then performed to further confirm the major active species during visible light photocatalytic degradation of resorcinol. These results are displayed in Figure 12 and show that when tert-butanol $(\bullet \mathrm{OH}$ scavenger) is added to the solution, minimal change in degradation rate is observed. However, p-benzoquinone $\left(\bullet \mathrm{O}_{2}{ }^{-}\right.$scavenger $)$or ammonium oxalate $\left(\mathrm{h}^{+}\right.$scavenger) present significate attenuation of the degradation rate when added to solution [116]. These results agree with the photocatalytic mechanism developed based on band position calculations.

Finally, the mechanistic results were combined with LC-MS data to propose a possible photocatalytic degradation pathway for resorcinol in the presence of $\mathrm{Bi}_{4} \mathrm{O}_{5} \mathrm{Br}_{0.6} \mathrm{I}_{1.4}$ under visible light irradiation. In mass spectra collected for degradation samples, fragment ions with $m / z=89,109$, 147 , and 239 were detected. The $m / z=109$ fragment was identified as resorcinol, while the remaining fragments were attributed to the production of degradation intermediates [116]. The identified intermediates were used to propose the degradation pathway for resorcinol shown in Figure 13. Compounds 1-4 were identified as the intermediates by LC-MS and compounds 5 and $\mathbf{6}$ were included based on previous work on resorcinol degradation [117]. The proposed degradation pathway suggests that $\bullet \mathrm{OH}$ plays an important role in initiating the removal of resorcinol, while the more prevalent $\bullet \mathrm{O}_{2}{ }^{-}$and $\mathrm{h}^{+}$species in this system act primarily to further break down degradation intermediates. 


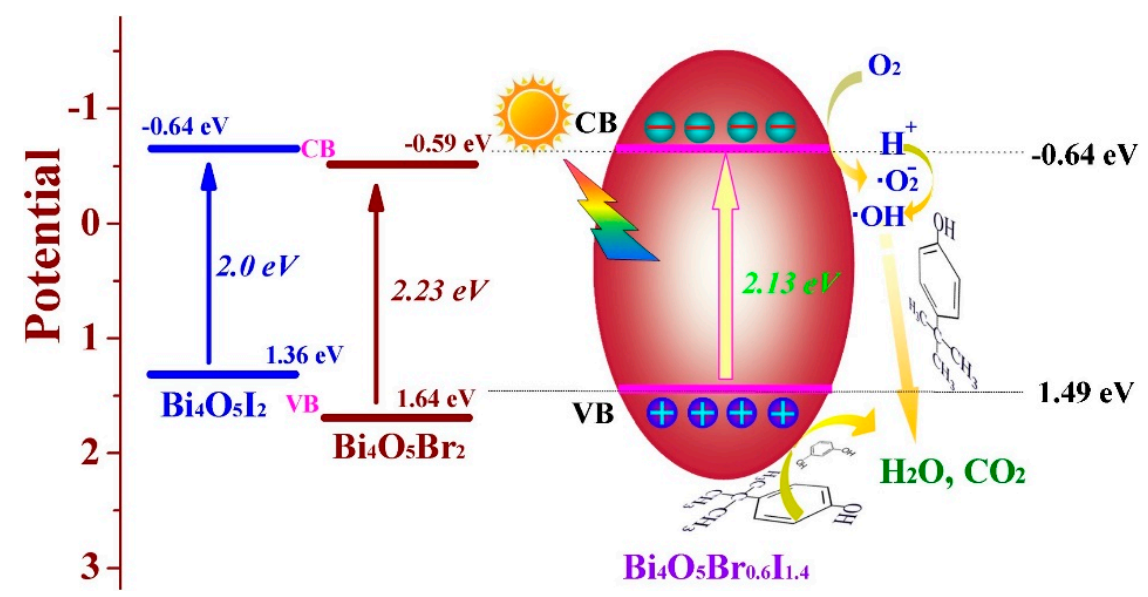

Figure 11. Mechanism for the photocatalytic degradation of phenolic compounds in the presence of $\mathrm{Bi}_{4} \mathrm{O}_{5} \mathrm{Br}_{0.6} \mathrm{I}_{1.4}$ under visible light [116]. Copyright Elsevier 2018.

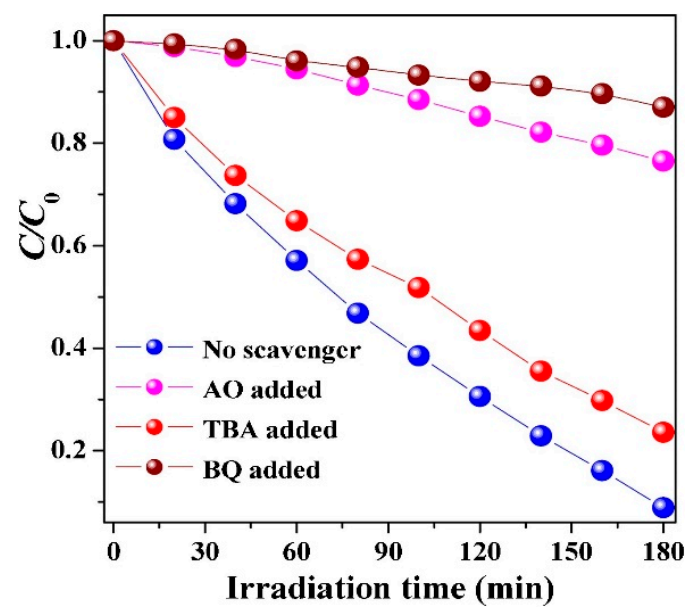

Figure 12. Evaluation of trapping agents based on a zeroth-order degradation plot of resorcinol given exposure to $\mathrm{Bi}_{4} \mathrm{O}_{5} \mathrm{Br}_{0.6} \mathrm{I}_{1.4}$ and visible light [116]. Copyright Elsevier 2018.

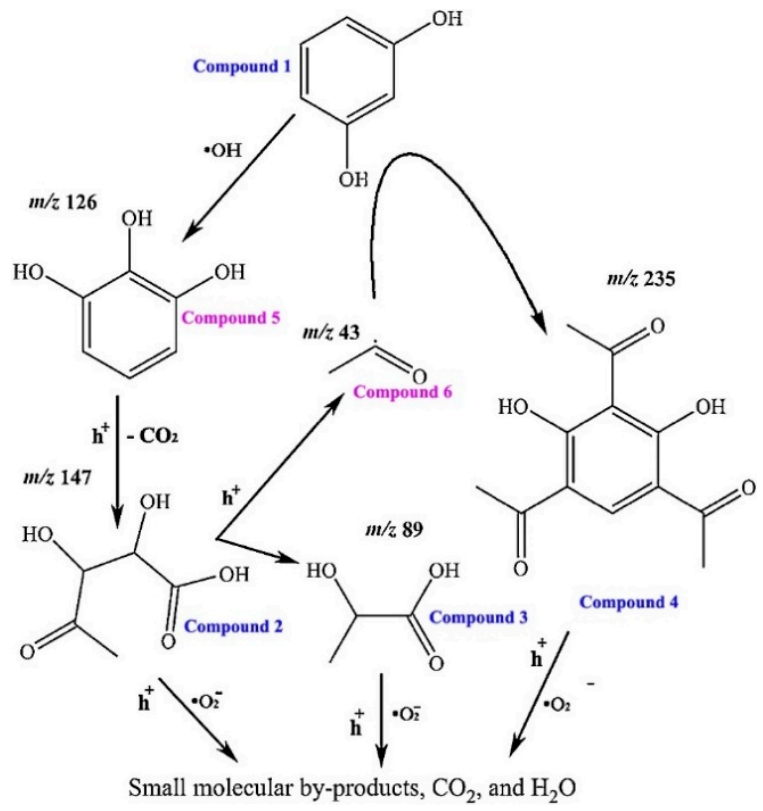

Figure 13. Proposed photocatalytic mechanisms of resorcinol given exposure to $\mathrm{Bi}_{4} \mathrm{O}_{5} \mathrm{Br}_{\mathrm{x}} \mathrm{I}_{2-\mathrm{x}}$ and visible light [116]. Copyright Elsevier 2018. 


\section{Investigation of BiOCl Photocatalytic Degradation Mechanism via Identification of Intermediates by LC-MS/MS}

Further investigation of BiOX photocatalysts for degradation of POPs was undertaken using ibuprofen as a model aqueous pharmaceutical pollutant [118]. While the photocatalytic degradation of ibuprofen (IBP) has been previously investigated, this was the first study to determine the mechanism of its removal by BiOX degradation using LC-MS/MS to characterize the production of intermediates throughout the process. Previous studies indicated that both $\mathrm{BiOCl}$ and $\mathrm{BiOBr}$ dramatically reduced observable IBP levels, and that this reduction consisted primarily of IBP adsorption to $\mathrm{BiOCl}$ or BiOBr $[119,120]$. However, several photodegradation products were identified via LC-MS/MS analysis of IBP samples photodegraded by BiOCl [118].

IBP was chosen as a model pollutant for this study due to its widespread availability as an over-the-counter Non-Steroidal Anti-inflammatory Drug (NSAID). IBP has been established as a potential public health risk [121] which has led to concern over the photochemical fate of the drug [6,7]. Removal of these and similar pollutants in low concentrations from water supplies is a vital challenge to maintaining high public health standards. The degradation of IBP in aqueous solutions has been studied under a wide variety of photolytic [7,122-128] and photocatalytic [129-131] conditions, with the general conclusion that complete mineralization is not achieved, and that the photoproducts have similar toxicity to IBP. This establishes a clear need to develop advanced photocatalytic materials capable of complete removal of IBP from aqueous solutions.

IBP photodegradation trials were conducted by first dissolving IBP in a minimal amount of methanol, before diluting with water to form a $100 \mathrm{ppm}(100 \mathrm{mg} / \mathrm{L}) \mathrm{IBP}$ stock solution. This stock solution was transferred into a quartz flask and diluted 1:10 with water to form a $10 \mathrm{ppm}$ sample solution. To this solution, $25 \mathrm{mg}$ of $\mathrm{BiOCl}$ was added and the mixture was allowed to stir for $15 \mathrm{~min}$ in the dark to achieve adsorption/desorption equilibrium. Aliquots taken from the reaction mixture were subjected to High Performance Liquid Chromatography with Diode-Array Detection (HPLC-DAD) in order to quantify IBP removal as well as LC-MS/MS to characterize the evolution of intermediates throughout the photocatalytic process. HPLC-DAD results indicate that two primary processes contribute to the complete photocatalytic degradation of IBP: (1) the "primary" degradation process in which IBP is decarboxylated and converted to 4-isobutylacetophenone (IBAP) and 1-(4-isobutylphenyl)ethanol (IBPE); and (2) the "secondary" degradation process where IBAP reacts further with hydroxyl radicals. Figure $14 \mathrm{~A}$ shows the progression of the primary degradation process as monitored by HPLC-DAD. IBP is shown to be completely removed from the solution within $20 \mathrm{~min}$, while IBPE and IBAP are produced at similar rates. After initial production, both IBPE and IBAP are found to slowly degrade as well, with IBAP degradation proceeding at a faster rate than IBPE. 

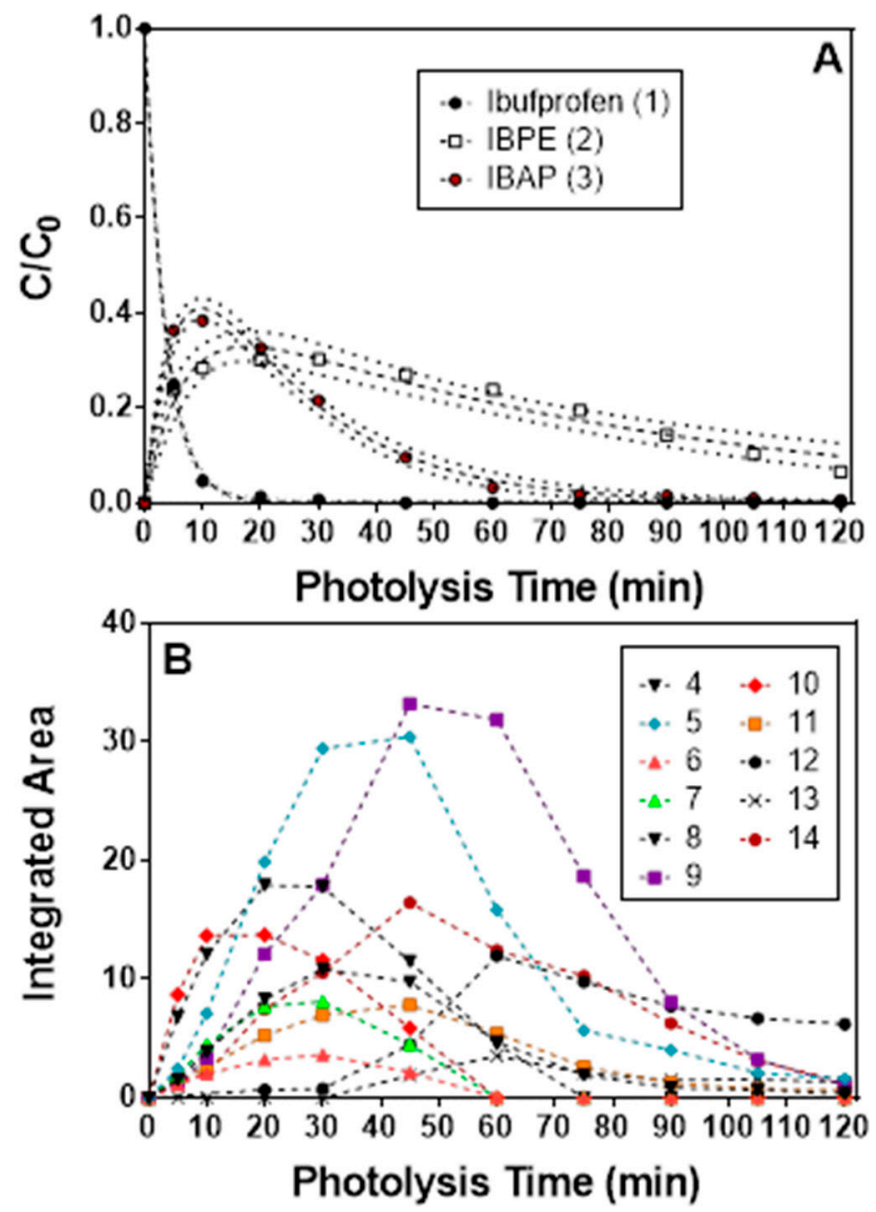

Figure 14. (a) Zeroth-order degradation plot for IBP, IBPE, and IBAP treated with BiOCl. This was derived via HPLC-DAD at 210-nm. (b) Integrated areas for signals corresponding with proposed intermediates. Said intermediates are identified in Table 3. Reused with permission from reference [118]. Copyright Elsevier 2018.

HPLC-DAD was used to detect 11 total secondary photoproducts 4-14 (Figure 14B). In order to structurally characterize these photoproducts, samples from photocatalytic degradation trials of IBP using $\mathrm{BiOCl}$ as a photocatalyst were analyzed via reversed-phase, positive-ion nanoelectrospray ionization LC-MS/MS. This analysis allows for determination of molecular formulas of the photocatalytic degradation products. These results including ions detected and molecular formula are summarized in Table 3. 
Table 3. Compounds identified by HPLC-DAD and LC-MS/MS. Reused with permission from reference [118]. Copyright Elsevier 2018.

\begin{tabular}{|c|c|c|c|c|c|c|c|}
\hline $\begin{array}{l}\text { Compound } \\
\text { Number }^{\mathrm{a}}\end{array}$ & $\begin{array}{l}\text { Retention Time } \\
\text { (HPLC; min) }\end{array}$ & $\begin{array}{l}\text { Retention Time } \\
\text { (LCMS; min) }\end{array}$ & 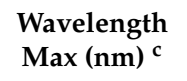 & $\begin{array}{l}\text { Molecular } \\
\text { Formula }\end{array}$ & $\begin{array}{l}\text { Exact Mass } \\
\text { (Predicted) } \\
\text { d }\end{array}$ & $\begin{array}{c}\text { Ions Detected, } \\
\text { MS }\end{array}$ & Product Ions Detected, MS/MS ${ }^{\mathrm{i}}$ \\
\hline 1 (IBP) & 19.29 & 25.87 & 220,264 & $\mathrm{C}_{13} \mathrm{H}_{18} \mathrm{O}_{2}$ & 206.131 & $\begin{array}{l}224.165^{\mathrm{f}} \\
207.138^{\mathrm{e}}\end{array}$ & $\begin{array}{c}\text { 224.16; } 161.13\left(-\mathrm{CO}_{2} \mathrm{H}\right) ; 119.08\left(-\mathrm{C}_{3} \mathrm{H}_{6}\right) ; \\
\text { 105.07 }\left(\mathrm{C}_{8} \mathrm{H}_{9}^{+}\right) ; 91.05\left(\mathrm{C}_{7} \mathrm{H}_{7}^{+}\right) ; 57.07 \\
\left(\mathrm{C}_{4} \mathrm{H}_{9}^{+}\right) ; 43.06\left(\mathrm{C}_{3} \mathrm{H}_{7}^{+}\right) ; 41.04\left(\mathrm{C}_{3} \mathrm{H}_{5}^{+}\right)\end{array}$ \\
\hline 2 (IBPE) & 18.01 & 24.43 & 220,264 & $\mathrm{C}_{12} \mathrm{H}_{18} \mathrm{O}$ & 178.136 & $161.132 \mathrm{~g}$ & $\begin{array}{l}161.13 ; 119.08\left(-\mathrm{C}_{3} \mathrm{H}_{6}\right) ; 117.07\left(-\mathrm{C}_{3} \mathrm{H}_{8}\right) ; \\
105.07\left(\mathrm{C}_{8} \mathrm{H}_{9}^{+}\right) ; 91.05\left(\mathrm{C}_{7} \mathrm{H}_{7}^{+}\right) ; 57.07 \\
\left(\mathrm{C}_{4} \mathrm{H}_{9}^{+}\right) ; 43.06\left(\mathrm{C}_{3} \mathrm{H}_{7}^{+}\right) ; 41.04\left(\mathrm{C}_{3} \mathrm{H}_{5}^{+}\right)\end{array}$ \\
\hline 3 (IBAP) & 20.93 & 26.97 & 255 & $\mathrm{C}_{12} \mathrm{H}_{16} \mathrm{O}$ & 176.120 & $177.127^{\mathrm{e}}$ & 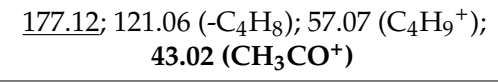 \\
\hline 4 & 4.64 & 11.06 & 310 & $\mathrm{C}_{12} \mathrm{H}_{18} \mathrm{O}_{3}$ & 210.126 & $\begin{array}{l}193.123^{g} \\
233.116^{h}\end{array}$ & $-j$ \\
\hline 5 & 5.58 & $-{ }^{b}$ & $254,300(w)$ & $-\mathrm{b}$ & $-{ }^{b}$ & $-{ }^{b}$ & $-{ }^{b}$ \\
\hline 6 & 7.25 & $-{ }^{b}$ & 320 & $-{ }^{b}$ & $-{ }^{b}$ & $-{ }^{b}$ & $-{ }^{b}$ \\
\hline 7 & 7.97 & 14.40 & 258 & $\mathrm{C}_{12} \mathrm{H}_{18} \mathrm{O}_{3}$ & 210.126 & $\begin{array}{l}193.123^{\mathrm{g}} \\
233.116^{\mathrm{h}}\end{array}$ & $\frac{193.123 ; 175.10\left(-\mathrm{H}_{2} \mathrm{O}\right) ; 137.06\left(-\mathrm{C}_{4} \mathrm{H}_{8}\right) ;}{57.07\left(\mathrm{C}_{4} \mathrm{H}_{9}^{+}\right) ; \mathbf{4 3 . 0 2}\left(\mathbf{C H}_{3} \mathbf{C O}^{+}\right)}$ \\
\hline 8 & 10.68 & 17.31 & 254 & $\mathrm{C}_{12} \mathrm{H}_{16} \mathrm{O}_{2}$ & 192.115 & $193.119^{\mathrm{e}}$ & \\
\hline 9 & 11.54 & 17.83 & 296 & $\mathrm{C}_{12} \mathrm{H}_{16} \mathrm{O}_{3}$ & 208.1099 & $209.117^{c}$ & 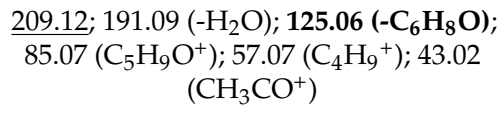 \\
\hline 10 & 14.37 & $-{ }^{b}$ & $260,300(w)$ & $-{ }^{b}$ & $-{ }^{\mathrm{b}}$ & $-{ }^{\mathrm{b}}$ & $-{ }^{\mathrm{b}}$ \\
\hline 11 & 16.61 & 23.22 & $220,264,315$ & $\mathrm{C}_{12} \mathrm{H}_{16} \mathrm{O}_{2}$ & 192.115 & $193.119^{\mathrm{e}}$ & $\underline{193.12} ; 57.07\left(\mathrm{C}_{4} \mathrm{H}_{9}^{+}\right) ; \mathbf{4 3 . 0 2}\left(\mathrm{CH}_{3} \mathrm{CO}^{+}\right)$ \\
\hline 12 & 17.00 & 23.42 & 312 & $\mathrm{C}_{11} \mathrm{H}_{16} \mathrm{O}$ & 164.120 & $165.127^{\mathrm{e}}$ & $\underline{165.13} ; 147.12\left(-\mathrm{H}_{2} \mathrm{O}\right) ; \mathbf{4 3 . 0 2}\left(\mathrm{CH}_{3} \mathrm{CO}^{+}\right)$ \\
\hline 13 & 17.85 & 24.18 & 305 & $\mathrm{C}_{11} \mathrm{H}_{16} \mathrm{O}$ & 164.120 & $165.127^{\mathrm{e}}$ & $-j$ \\
\hline 14 & 22.63 & 28.49 & $215,263,327$ & $\mathrm{C}_{12} \mathrm{H}_{16} \mathrm{O}_{2}$ & 192.115 & $193.122^{\mathrm{e}}$ & $\frac{193.12 ; 175.11\left(-\mathrm{H}_{2} \mathrm{O}\right) ; 137.07\left(-\mathrm{C}_{4} \mathrm{H}_{8}\right) ;}{57.07\left(\mathrm{C}_{4} \mathrm{H}_{9}^{+}\right) ; \mathbf{4 3 . 0 2}\left(\mathrm{CH}_{3} \mathbf{C O}^{+}\right)}$ \\
\hline
\end{tabular}

a IBP = ibuprofen; IBPE = 1-(4-isobutylphenyl)ethanol; IBAP = 4-Isopropylacetophenone (IBAP); ${ }^{\mathrm{b}}$ No peak detected by (+)nanoESI-LCMS to correlate with HPLC data; ${ }^{\mathrm{c}}$ Full UV/Vis DAD spectra; solvent varied based upon gradient composition for peak elution; (w) signifies a weak absorption band; ${ }^{\mathrm{d}}$ monoisotopic mass; ${ }^{\mathrm{e}}\left[\mathrm{M}+\mathrm{H}^{+} ;{ }^{\mathrm{f}}[\mathrm{M}+\mathrm{NH}]^{+} ; \mathrm{g}\left[\mathrm{MH}-\mathrm{H}_{2} \mathrm{O}\right]^{+}\right.$; ${ }^{\mathrm{h}}[\mathrm{M}+\mathrm{Na}]^{+}$; ${ }^{\mathrm{i}}$ precursor ion is underlined; base peak in spectrum appears in bold; collision energy $=15 \mathrm{eV} ;{ }^{\mathrm{j}}$ no MS/MS data collected. 
Isomeric hydroxylated forms of IBP have been reported in previous studies (pathway a, Figure 15) under IBP degradation conditions including direct photolysis [125], $\mathrm{TiO}_{2}$ photocatalysis [123,132], sonophotocatalysis [133], and pulse radiolysis [134]. Patterson et al. reported that after treatment with $\mathrm{BiOCl}$ and limited light exposure the signals for hydroxylated IBP isomers were very low in intensity (pathway a, Figure 15) [118]. In contrast, strong evidence was found that $\mathrm{TiO}_{2}$ photocatalysis and direct photolysis are responsible for the production of these hydroxylated IBPs [118]. Thus, the researchers determined that pathway a (Figure 15) does not play a major role in $\mathrm{BiOCl}$ photocatalytic degradation of IBP. It was proposed that this observation is a potential consequence of relatively low rates of hydroxyl radical production typically observed for $\mathrm{BiOCl}$, combined with rapid decarboxylation of IBP $[135,136]$.

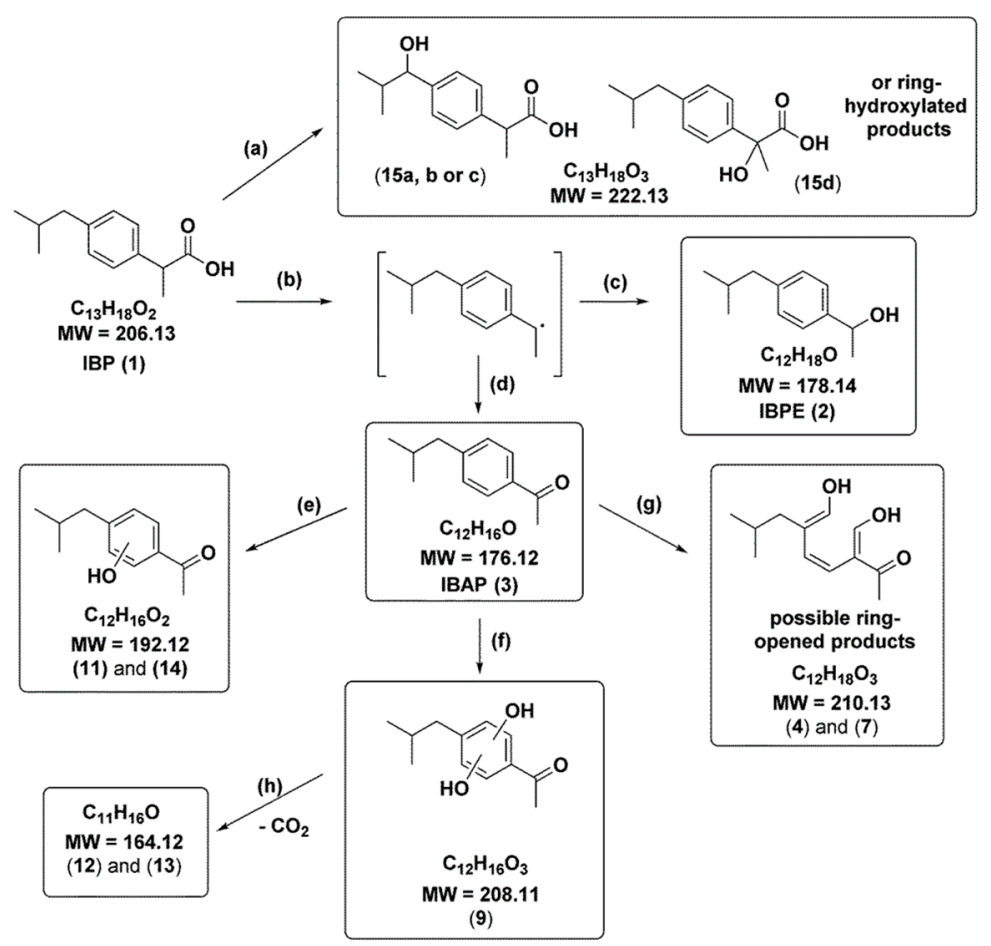

Figure 15. Proposed products from the photocatalytic breakdown of IBP. Reused with permission from reference [118]. Copyright Elsevier 2018.

This report showed that $\mathrm{BiOCl}$ presents high activity for photocatalytic degradation and removal of IBP from aqueous solutions. This also demonstrates that adsorption is not the primary mechanism through which BiOCl nanosheets employed in this study remove IBP from water [118]. The photodegradation pathway proposed is initiated through decarboxylation of IBP via oxidation by electron holes $\left(\mathrm{h}^{+}\right)$in the valence band of $\mathrm{BiOCl}$. This decarboxylation leads to formation of benzyl radicals (pathway b, Figure 15), which are converted to both IBPE (pathway c, Figure 15) as well as IBAP (pathway d, Figure 15). Further photocatalytic degradation experiments indicated that only IBAP reacts further under these conditions to yield 11 secondary photocatalytic degradation products. Photodegradation of IBAP was proposed to be initiated by the hydroxyl radicals attacking IBAP on the aromatic ring via pathways $\mathbf{d}-\mathbf{f}$ (Figure 15). This attack results in the production of the observed hydroxyl-substituted IBAP derivatives [118]. Overall the results support that initially, IBAP is formed via decarbaoxylation by BiOCl before subsequent degradation of IBAP by radical oxidation on the aromatic ring of IBAP. Structurally similar pharmaceuticals, such as naproxen, benoxaprofen and ketoprofen may also be activated by $\mathrm{BiOCl}$ photocatalysis and should be targeted for future work. The structural alterations to pollutants during photocatalytic are shown to impact 
photocatalytic degradation rates and should be taken under consideration when designing any photodegradation process.

\section{6. $\mathrm{Cu}(\mathrm{II})$-Doped BiOCl for Photocatalytic Degradation of Atrazine with Radical Scavenging}

A recently published study demonstrates how $\mathrm{Cu}$-doped $\mathrm{BiOCl}$ compounds interact with atrazine to facilitate photodegradation, with an emphasis on identification of key radical species produced during the process [137]. Doping of photocatalysts has been a popular method to increase light utilization and efficiency. Effective use of photocatalysts relies on increased degradation of pollutants and photochemical reactivity to a variety of wavelengths. One way that improvement of photocatalytic activity is approached is through photocatalyst doping with metal ions that act as electron traps thereby preventing the recombination of electron holes $\left(\mathrm{h}^{+}\right)$and excited-state electrons $\left(\mathrm{e}^{-}\right)[14,138]$. Previous reports have shown that photocatalytic degradation rates of metal-doped photocatalysts can increase compared to the unaltered material. In particular, the addition of copper (II) ions have shown significant improvement in photocatalytic degradation rates as a result of reduced recombination [139]. Excited-state transfer of electrons to the metal dopant from the conduction band of bismuth oxyhalide facilitates the prevention of recombination and extends the lifetime of excited state electrons, allowing more photocatalytic reactions to occur $[50,140]$.

$\mathrm{Cu}-\mathrm{BiOCl}$ has been used to photocatalytically degrade atrazine [137]. Active species trapping experiments demonstrate the pathways through which $\mathrm{Cu}-\mathrm{BiOCl}$ acts to remove organic pollutants from water. Dark adsorption trials indicated that atrazine was not significantly adsorbed onto the surface of either $\mathrm{BiOCl}$ nor $\mathrm{Cu}-\mathrm{BiOCl}$. This shows that reactive species are active during the photocatalytic process and that atrazine removal is not due to adsorption. UV-Vis analysis of aliquots from photocatalytic degradation trials indicate that $65 \%$ of the original atrazine concentration remain after $30 \mathrm{~min}$. of $\mathrm{BiOCl}$ photocatalysis, while $71 \%$ of atrazine remains after $\mathrm{Cu}-\mathrm{BiOCl}$ photocatalysis. The photocatalytic degradation rates of $\mathrm{Cu}-\mathrm{BiOCl}$ and $\mathrm{BiOCl}$ are qualitatively similar, suggesting that prevention of recombination is not the only factor affecting the rate. To further probe this observation, trials were performed with radical scavengers present to determine the origin of photocatalytic reactivity for this system.

The results of radical scavenging experiments for $\mathrm{Cu}-\mathrm{BiOCl}$ and $\mathrm{BiOCl}$ are shown in Figures 16 and 17, respectively [137]. Based on these results, it is clear that for $\mathrm{BiOCl}$, hydroxyl radicals and $\mathrm{h}^{+}$ feature prominently in photocatalytic degradation of atrazine, while superoxide radicals play only a minor role. Interestingly, radical scavenging experiments with $\mathrm{Cu}-\mathrm{BiOCl}$ exhibit a similar trend, with normal degradation behavior observed upon addition of IPA or BQ, while atrazine removal is completely quenched by the addition of KI [137]. Atrazine removal percentages The major difference noted for these trials was that hydroxyl radical activity was more pronounced for $\mathrm{BiOCl}$ than for $\mathrm{Cu}-\mathrm{BiOCl}$, suggesting that production of hydroxyl radicals may have been reduced through the addition of copper ions. 


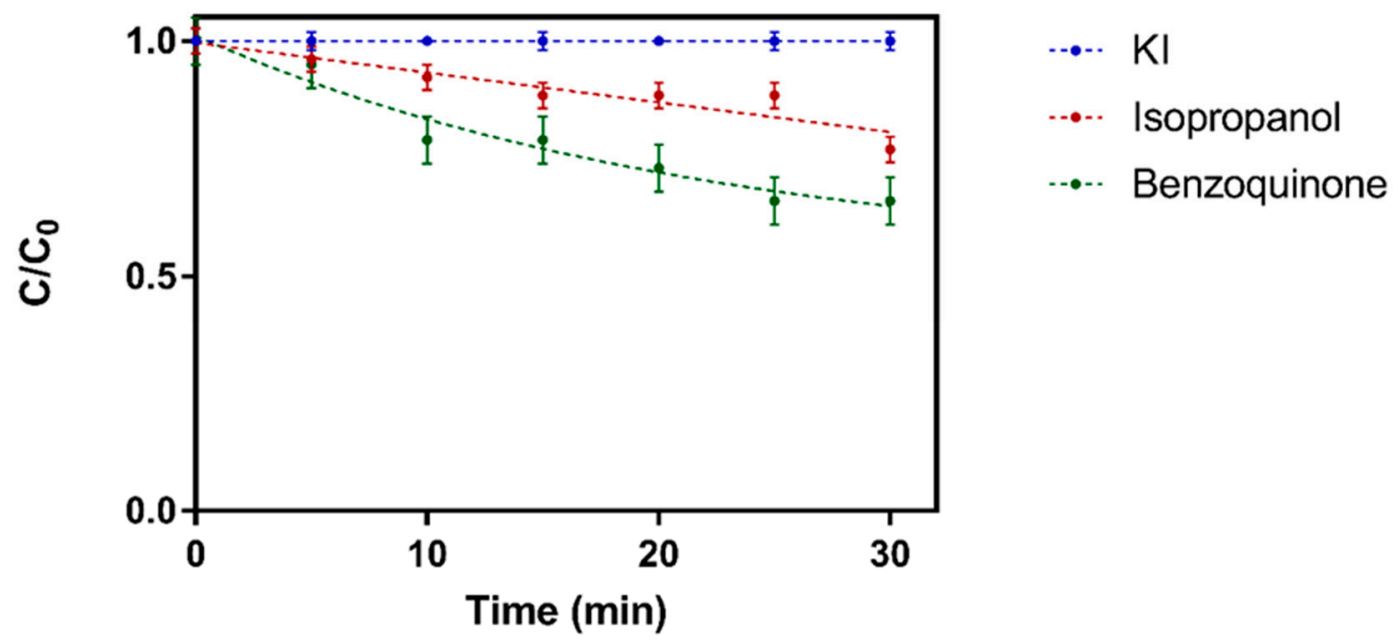

Figure 16. Zeroth-order degradation plot for Atrazine given treatment with $\mathrm{BiOCl}$ in the presence of isopropanol, KI and benzoquinone and $254 \mathrm{~nm}$ light. Reused with permission from reference [137]. Copyright Elsevier 2018.

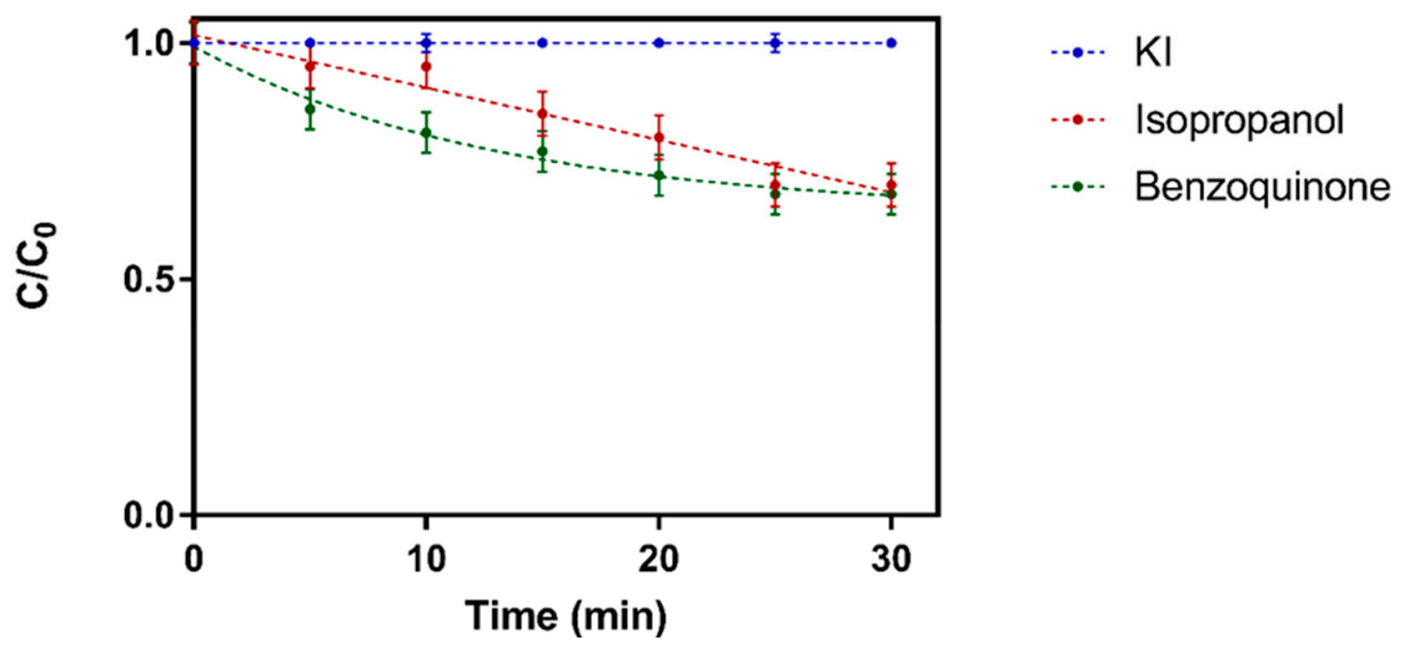

Figure 17. Zeroth order degradation plot for Atrazine given exposure to $\mathrm{Cu}-\mathrm{BiOCl}$ photocatalysis in the presence of isopropanol, KI and benzoquinone and $254 \mathrm{~nm}$ light. Reused with permission from reference [137]. Copyright Elsevier 2018.

Results from radical scavenging and photocatalytic degradation trials were used to formulate a proposed mechanistic pathway for photodegradation of atrazine with $\mathrm{Cu}-\mathrm{BiOCl}$. Initially, absorption of irradiation $(h v)$ by BiOCl results in the excitation of an electron to the conduction band from the valence band of $\mathrm{BiOCl}$ (Equation (1)). This process leads to the generation of an electron hole $\left(\mathrm{h}^{+}\right)$ and an excited electron ( $\mathrm{e}^{-}$). Equations (2) and (3) show that photo-induced separation of $\mathrm{e}^{-}$and $\mathrm{h}^{+}$ occur in $\mathrm{Cu}-\mathrm{BiOCl}$ occur upon photoirradiation through electron-transfer reducuction of $\mathrm{Cu}$ (II) species on the surface of $\mathrm{BiOCl}$ to $\mathrm{Cu}(\mathrm{I})$ and subsequent oxidation by molecular oxygen. It is proposed that the introduction of a source of molecular oxygen to this system would result in greater production of superoxide radicals, as well as reduced rates of electron-hole recombination. This electron transfer has been previously shown to be assisted by the presence of $\mathrm{Cu}$ (II) ions aligned with the conduction band of $\mathrm{BiOCl}[141]$.

$$
\begin{gathered}
\mathrm{BiOCl}+h v \rightarrow \mathrm{e}^{-}+\mathrm{h}^{+} \\
\mathrm{Cu}^{2+}+\mathrm{e}^{-} \rightarrow \mathrm{Cu}^{+} \\
\mathrm{Cu}^{+}+\mathrm{O}_{2} \rightarrow \mathrm{Cu}^{2+}+\mathrm{O}_{2}^{-}
\end{gathered}
$$




$$
\mathrm{O}_{2}{ }^{-}+\mathrm{ATZ} \rightarrow \text { Degradation Products }
$$

$$
\mathrm{ATZ}+\mathrm{h}^{+} \rightarrow \mathrm{ATZ}^{+}
$$

$$
\mathrm{ATZ}^{+} \rightarrow \text { Degradation Products }
$$

Since radical scavenging trials indicate that hydroxyl radicals do not play a significant role in photocatalytic degradation of atrazine with $\mathrm{BiOCl}$, this is not suggested as a primary reactive pathway. Production of hydroxyl radicals is even less emphasized during photocatalytic degradation of atrazine with $\mathrm{Cu}-\mathrm{BiOCl}$. The formation of degradation products is proposed to originate through two major mechanisms. First, the reaction of superoxide radicals generated at the conduction band of $\mathrm{BiOCl}$ during the photocatalytic process react with atrazine forming degradation products (Equation (4)). This pathway may be suppressed in our results due to the transfer of excited state electrons from the conduction band of $\mathrm{BiOCl}$ to the copper ions. More importantly, direct interaction of atrazine with electron holes in the valence band of $\mathrm{BiOCl}$ were the major degradation pathway indicated for photocatalytic degradation of atrazine. It is proposed that this reaction proceeds via electron transfer to the valence band of $\mathrm{BiOCl}$ directly from atrazine thereby generating electron-deficent $\mathrm{ATZ}^{+}$(Equation (5)) [137]. Subsequent degradation reactions of $\mathrm{ATZ}^{+}$occur due to this species' inherent instability forming further degradation products (Equation (6)).

\section{Summary and Conclusions}

Photocatalysis is an important emerging technology that has seen intense interest in recent years. It has been used in applications including generation of solar fuels and remediation of environmental pollutants. Bismuth oxyhalides are a new class of photocatalysts that possess unique properties that have been shown to result in improved photocatalytic activity compared to traditional photocatalysts. Numerous articles have been published that focus on synthesis and doping strategies of BiOX to further improve their photocatalytic activity. While BiOX compounds have been previously shown to be useful in degradation of persistent organic pollutants, detailed studies of the photocatalytic degradation mechanism have been largely neglected. This review discusses the high activity that bismuth oxyhalide photocatalysts present for the degradation of pharmaceuticals and pesticides as well as the photocatalytic degradation mechanisms associated with them. The degradation mechanisms discussed are investigated through LC-MS/MS characterization of photocatalytic degradation intermediates as well as through radical scavenging experiments. These studies demonstrate that bismuth oxyhalides do not simply act to adsorb persistent organic pollutants, but that they directly react with pollutant molecules to initiate the photodegradation process. It has been shown that bismuth oxyhalides can react quickly, directly, and selectively with organic moieties such as sterols, carboxylic acids, and amines. In future work, these properties should be further investigated and exploited in order to expand the application of these materials to photocatalytic remediation of additional organic pollutants as well as the synthesis of fine chemicals.

Funding: This research received no external funding.

Conflicts of Interest: Los Alamos National Laboratory strongly supports academic freedom and a researcher's right to publish; as an institution, however, the Laboratory does not endorse the viewpoint of a publication or guarantee its technical correctness.

\section{References}

1. Offermanns, S.; Rosenthal, W. Encyclopedic Reference of Molecular Pharmacology, 1st ed.; Springer Verlag: Berlin, Germany, 2004.

2. Jones, O.A.; Lester, J.N.; Voulvoulis, N. Pharmaceuticals: A threat to drinking water? Trends Biotechnol. 2005, 23, 163-167. [CrossRef] [PubMed] 
3. Jux, U.; Baginski, R.M.; Arnold, H.-G.; Krönke, M.; Seng, P.N. Detection of pharmaceutical contaminations of river, pond, and tap water from Cologne (Germany) and surroundings. Int. J. Hyg. Environ. Heal. 2002, 205, 393-398. [CrossRef] [PubMed]

4. Kümmerer, K. Drugs in the environment: Emission of drugs, diagnostic aids and disinfectants into wastewater by hospitals in relation to other sources-A review. Chemosphere 2001, 45, 957-969. [CrossRef]

5. Jones, J.G. Pollution from Fish Farms. Water Environ. J. 1990, 4, 14-18. [CrossRef]

6. Richardson, M.L.; Bowron, J.M. The fate of pharmaceutical chemicals in the aquatic environment. J. Pharma. Pharmacol. 1985, 37, 1-12. [CrossRef]

7. Vione, D.; Maddigapu, P.R.; De Laurentiis, E.; Minella, M.; Pazzi, M.; Maurino, V.; Minero, C.; Kouras, S.; Richard, C. Modelling the photochemical fate of ibuprofen in surface waters. Water Res. 2011, 45, 6725-6736. [CrossRef] [PubMed]

8. Krasner, S.W.; Weinberg, H.S.; Richardson, S.D.; Pastor, S.J.; Chinn, R.; Sclimenti, M.J.; Onstad, G.D.; Thruston, A.D. Occurrence of a new generation of disinfection byproducts. Environ. Sci. Technol. 2006, 40, 7175-7185. [CrossRef]

9. Fujishima, A.; Honda, K.; Fujishima, A.; Honda, K. Electrochemical Photolysis of Water at a Semiconductor Electrode. Nature 1972, 238, 37. [CrossRef]

10. Carey, J.H.; Lawrence, J.; Tosine, H.M. Photodechlorination of PCB's in the Presence of Titanium Dioxide in Aqueous Suspensions. Bull. Environ. Contam. Toxicol. 1976, 16, 697-701. [CrossRef]

11. Mitzi, D.B.; Feild, C.A.; Harrison, W.T.A.; Guloy, A.M. A low-cost, high-efficiency solar cell based on dye-sensitized colloidal $\mathrm{TiO}_{2}$ films. Nature 1994, 367, 532-538. [CrossRef]

12. Ahern, J.C.; Fairchild, R.; Thomas, J.S.; Carr, J.; Patterson, H.H. Characterization of BiOX compounds as photocatalysts for the degradation of pharmaceuticals in water. Appl. Catal. B 2015, 179, 229-238. [CrossRef]

13. Ali, I.; Kim, J. Chemosphere Visible-light-assisted photocatalytic activity of bismuth- $\mathrm{TiO}_{2}$ nanotube composites for chromium reduction and dye degradation. Chemosphere 2018, 207, 285-292. [CrossRef] [PubMed]

14. Chen, S.M.; Lu, N.; Chen, J.Y.; Yang, C.Y.; Yeh, Y.P.; Feng, T.Y.; Shih, Y.H.; Kokulnathan, T.; Chen, D. Enhanced photocatalytic degradation of atrazine by platinized titanium dioxide under $352 \mathrm{~nm}$ irradiation. Water Sci. Technol. 2017, 75, 1128-1137. [CrossRef] [PubMed]

15. Cao, J.; Xu, B.; Luo, B.; Lin, H.; Chen, S. Preparation, characterization and visible-light photocatalytic activity of $\mathrm{AgI} / \mathrm{AgCl} / \mathrm{TiO}_{2}$. Appl. Surf. Sci. 2011, 257, 7083-7089. [CrossRef]

16. Bannister, F.A. The crystal structure of the bismuth oxyhalides. J. Miner. Soc. 1935, 24, 49-58. [CrossRef]

17. Huang, W.L.; Zhu, Q. Electronic structures of relaxed BiOX (X=F, Cl, Br, I) photocatalysts. Comp. Mater. Sci. 2008, 43, 1101-1108. [CrossRef]

18. Zhang, K.; Liu, C.; Huang, F.; Zheng, C.; Wang, W. Study of the electronic structure and photocatalytic activity of the BiOCl photocatalyst. Appl. Catal. B 2006, 68, 125-129. [CrossRef]

19. Zhang, L.; Wang, W.; Sun, S.; Jiang, D.; Gao, E. Selective transport of electron and hole among $\left\{\begin{array}{lll}0 & 0 & 1\end{array}\right\}$ and $\begin{cases}1 & 1\end{cases}$ $0\}$ facets of BiOCl for pure water splitting. Appl. Catal. B 2015, 162, 470-474. [CrossRef]

20. Ye, L.; Zan, L.; Tian, L.; Peng, T.; Zhang, J. The $\{001\}$ facets-dependent high photoactivity of BiOCl nanosheets. Chem. Commun. 2011, 47, 6951. [CrossRef]

21. Wu, D.; Ye, L.; Yip, H.Y.; Wong, P.K. Organic-free synthesis of $\{001\}$ facet dominated BiOBr nanosheets for selective photoreduction of $\mathrm{CO}_{2}$ to CO. Catal. Sci. Technol. 2017, 7, 265-271. [CrossRef]

22. Peng, Y.; Wang, D.; Zhou, H.-Y.; Xu, A.-W. Controlled synthesis of thin BiOCl nanosheets with exposed $\{001\}$ facets and enhanced photocatalytic activities. CrystEngComm 2015, 17, 3845-3851. [CrossRef]

23. Wang, D.-H.; Gao, G.-Q.; Zhang, Y.-W.; Zhou, L.-S.; Xu, A.-W.; Chen, W. Nanosheet-constructed porous BiOCl with dominant $\{001\}$ facets for superior photosensitized degradation. Nanoscale 2012, 4, 7780. [CrossRef] [PubMed]

24. Duan, F.; Wang, X.; Tan, T.; Chen, M. Highly exposed surface area of $\{001\}$ facets dominated BiOBr nanosheets with enhanced visible light photocatalytic activity. Phys. Chem. Chem. Phys. 2016, 18, 6113-6121. [CrossRef] [PubMed]

25. Haider, Z.; Zheng, J.Y.; Kang, Y.S. Surfactant free fabrication and improved charge carrier separation induced enhanced photocatalytic activity of $\{001\}$ facet exposed unique octagonal BiOCl nanosheets. Phys. Chem. Chem. Phys. 2016, 18, 19595-19604. [CrossRef] [PubMed] 
26. Xu, Y.; Xu, S.; Wang, S.; Zhang, Y.; Li, G. Citric acid modulated electrochemical synthesis and photocatalytic behavior of BiOCl nanoplates with exposed \{001\} facets. Dalt. Trans. 2014, 43, 479-485. [CrossRef] [PubMed]

27. Li, H.; Zhang, L. Oxygen vacancy induced selective silver deposition on the $\{001\}$ facets of $\mathrm{BiOCl}$ single-crystalline nanosheets for enhanced $\mathrm{Cr}(\mathrm{VI})$ and sodium pentachlorophenate removal under visible light. Nanoscale 2014, 6, 7805-7810. [CrossRef] [PubMed]

28. Kong, T.; Wei, X.; Zhu, G.; Huang, Y. First-principles studies on facet-dependent photocatalytic properties of BiOI $\{001\}$ surface. J. Mater. Sci. 2017, 52, 5686-5695. [CrossRef]

29. Li, H.; Shi, J.; Zhao, K.; Zhang, L. Sustainable molecular oxygen activation with oxygen vacancies on the $\{001\}$ facets of BiOCl nanosheets under solar light. Nanoscale 2014, 6, 14168-14173. [CrossRef] [PubMed]

30. Xiong, X.; Ding, L.; Wang, Q.; Li, Y.; Jiang, Q.; Hu, J. Synthesis and photocatalytic activity of BiOBr nanosheets with tunable exposed (0 10 ) facets. Appl. Catal. B 2016, 188, 283-291. [CrossRef]

31. Song, G.; Wu, X.; Xin, F.; Yin, X. $\mathrm{ZnFe}_{2} \mathrm{O}_{4}$ deposited on $\mathrm{BiOCl}$ with exposed (001) and (010) facets for photocatalytic reduction of $\mathrm{CO}_{2}$ in cyclohexanol. Front. Chem. Sci. Eng. 2017, 11, 197-204. [CrossRef]

32. Tan, C.; Zhu, G.; Hojamberdiev, M.; Okada, K.; Liang, J.; Luo, X.; Liu, P.; Liu, Y. $\mathrm{Co}_{3} \mathrm{O}_{4}$ nanoparticles-loaded $\mathrm{BiOCl}$ nanoplates with the dominant $\{001\}$ facets: Efficient photodegradation of organic dyes under visible light. Appl. Catal. B 2014, 152-153, 425-436. [CrossRef]

33. Ye, L.; Chen, J.; Tian, L.; Liu, J.; Peng, T.; Deng, K.; Zan, L. BiOI thin film via chemical vapor transport: Photocatalytic activity, durability, selectivity and mechanism. Appl. Catal. B 2013, 130-131, 1-7. [CrossRef]

34. Wu, Y.; Yuan, B.; Li, M.; Zhang, W.H.; Liu, Y.; Li, C. Well-defined BiOCl colloidal ultrathin nanosheets: Synthesis, characterization, and application in photocatalytic aerobic oxidation of secondary amines. Chem. Sci. 2015, 6, 1873-1878. [CrossRef] [PubMed]

35. Li, J.; Zhang, L.; Li, Y.; Yu, Y. Synthesis and internal electric field dependent photoreactivity of $\mathrm{Bi}_{3} \mathrm{O}_{4} \mathrm{Cl}$ single-crystalline nanosheets with high $\{001\}$ facet exposure percentages. Nanoscale 2014, 6, 167-171. [CrossRef] [PubMed]

36. Di, J.; Xia, J.; Ge, Y.; Xu, L.; Xu, H.; He, M.; Zhang, Q.; Li, H. Reactable ionic liquid-assisted rapid synthesis of BiOI hollow microspheres at room temperature with enhanced photocatalytic activity. J. Mater. Chem. A 2014, 2, 15864-15874. [CrossRef]

37. Xia, J.; Zhang, J.; Yin, S.; Li, H.; Xu, H.; Xu, L.; Zhang, Q. Advanced visible light photocatalytic properties of $\mathrm{BiOCl}$ micro/nanospheres synthesized via reactable ionic liquids. J. Phys. Chem. Solids 2013, 74, $298-304$. [CrossRef]

38. Xia, J.; Yin, S.; Li, H.; Xu, H.; Xu, L.; Zhang, Q. Enhanced photocatalytic activity of bismuth oxyiodine (BiOI) porous microspheres synthesized via reactable ionic liquid-assisted solvothermal method. Colloids Surf. A Physicochem. Eng. Asp. 2011, 387, 23-28. [CrossRef]

39. Xia, J.; Yin, S.; Li, H.; Xu, H.; Xu, L.; Xu, Y. Improved visible light photocatalytic activity of sphere-like $\mathrm{BiOBr}$ hollow and porous structures synthesized via a reactable ionic liquid. Dalt. Trans. 2011, 40, 5249-5258. [CrossRef]

40. Xia, J.; Yin, S.; Li, H.; Xu, H.; Yan, Y.; Zhang, Q. Self-assembly and enhanced photocatalytic properties of BiOI hollow microspheres via a reactable ionic liquid. Langmuir 2011, 27, 1200-1206. [CrossRef]

41. Xiong, J.; Jiao, Z.; Lu, G.; Ren, W.; Ye, J.; Bi, Y. Facile and rapid oxidation fabrication of BiOCl hierarchical nanostructures with enhanced photocatalytic properties. Chem. Eur. J. 2013, 19, 9472-9475. [CrossRef]

42. Zhang, X.; Ai, Z.; Jia, F.; Zhang, L. Generalized One-Pot Synthesis, Characterization, and Photocatalytic Activity of Hierarchical BiOX (X) Cl, Br, I) Nanoplate Microspheres. J. Phys. Chem. C 2008, 112, 747-753. [CrossRef]

43. Kang, S.; Pawar, R.C.; Lee, C.S. Decoration of Au nanoparticles onto BiOCl sheets for enhanced photocatalytic performance under visible irradiation for the degradation of RhB dye. J. Exp. Nanosci. 2016, 11, 853-871. [CrossRef]

44. Xu, L.; He, F.; Wang, C.; Gai, S.; Gulzar, A.; Yang, D.; Zhong, C.; Yang, P. Lanthanide-doped bismuth oxobromide nanosheets for self-activated photodynamic therapy. J. Mater. Chem. B 2017, 5, 7939-7948. [CrossRef]

45. Zhang, H.; Liu, L.; Zhou, Z. Towards better photocatalysts: First-principles studies of the alloying effects on the photocatalytic activities of bismuth oxyhalides under visible light. Phys. Chem. Chem. Phys. 2012, 14, 1286-1292. [CrossRef] [PubMed] 
46. Xia, J.; Xu, L.; Zhang, J.; Yin, S.; Li, H.; Xu, H.; Di, J. Improved visible light photocatalytic properties of $\mathrm{Fe} / \mathrm{BiOCl}$ microspheres synthesized via self-doped reactable ionic liquids. CrystEngComm 2013, 15, 10132. [CrossRef]

47. Yu, Y.; Cao, C.; Liu, H.; Li, P.; Wei, F.; Jiang, Y.; Song, W. A Bi/BiOCl heterojunction photocatalyst with enhanced electron-hole separation and excellent visible light photodegrading activity. J. Mater. Chem. A 2014, 2, 1677-1681. [CrossRef]

48. Ye, L.; Liu, J.; Gong, C.; Tian, L.; Peng, T.; Zan, L. Two Different Roles of Metallic Ag on Ag/AgX/BiOX (X= Cl, Br) Visible Light Photocatalysts: Surface Plasmon Resonance and Z-Scheme Bridge. ACS Catal. 2012, 2, 1677-1683. [CrossRef]

49. Lin, H.; Li, X.; Cao, J.; Chen, S.; Chen, Y. Novel I-doped BiOBr composites: Modulated valence bands and largely enhanced visible light phtotocatalytic activities. Catal. Commun. 2014, 49, 87-91. [CrossRef]

50. Liu, Z.; Liu, J.; Wang, H.; Cao, G.; Niu, J. Boron-doped bismuth oxybromide microspheres with enhanced surface hydroxyl groups: Synthesis, characterization and dramatic photocatalytic activity. J. Colloid Interface Sci. 2016, 463, 324-331. [CrossRef]

51. Lee, W.W.; Lu, C.S.; Chuang, C.W.; Chen, Y.J.; Fu, J.Y.; Siao, C.W.; Chen, C.C. Synthesis of bismuth oxyiodides and their composites: Characterization, photocatalytic activity, and degradation mechanisms. RSC Adv. 2015, 5, 23450-23463. [CrossRef]

52. Li, Q.; Zhao, X.; Yang, J.; Jia, C.-J.; Jin, Z.; Fan, W. Exploring the effects of nanocrystal facet orientations in g- $\mathrm{C}_{3} \mathrm{~N}_{4} / \mathrm{BiOCl}$ heterostructures on photocatalytic performance. Nanoscale 2015, 7, 18971-18983. [CrossRef] [PubMed]

53. Cheng, H.; Huang, B.; Dai, Y. Engineering BiOX $(\mathrm{X}=\mathrm{Cl}, \mathrm{Br}, \mathrm{I})$ nanostructures for highly efficient photocatalytic applications. Nanoscale 2014, 6, 2009-2026. [CrossRef] [PubMed]

54. Sun, M.; Zhao, Q.; Du, C.; Liu, Z. Enhanced visible light photocatalytic activity in $\mathrm{BiOCl} / \mathrm{SnO}_{2}$ : Heterojunction of two wide band-gap semiconductors. RSC Adv. 2015, 5, 22740-22752. [CrossRef]

55. Liu, R.; Wu, Z.; Tian, J.; Yu, C.; Li, S.; Yang, K.; Liu, X.; Liu, M. The excellent dye-photosensitized degradation performance over hierarchical $\mathrm{BiOCl}$ nanostructures fabricated via a facile microwave-hydrothermal process. New J. Chem. 2018, 42, 137-149. [CrossRef]

56. Li, G.; Jiang, B.; Xiao, S.; Lian, Z.; Zhang, D.; Yu, J.C.; Li, H. An efficient dye-sensitized BiOCl photocatalyst for air and water purification under visible light irradiation. Environ. Sci. Process. Impacts 2014, 16, 1975-1980. [CrossRef] [PubMed]

57. Zhang, X.; Wang, C.-Y.; Wang, L.-W.; Huang, G.-X.; Wang, W.-K.; Yu, H.-Q. Fabrication of BiOBrxI1-x photocatalysts with tunable visible light catalytic activity by modulating band structures. Sci. Rep. 2016, 6, 22800. [CrossRef] [PubMed]

58. Jia, X.; Cao, J.; Lin, H.; Zhang, M.; Guo, X.; Chen, S. Transforming type-I to type-II heterostructure photocatalyst via energy band engineering: A case study of I-BiOCl/I-BiOBr. Appl. Catal. B 2017, 204, 505-514. [CrossRef]

59. Sánchez-Rodríguez, D.; Méndez Medrano, M.G.; Remita, H.; Escobar-Barrios, V. Photocatalytic properties of $\mathrm{BiOCl}-\mathrm{TiO}_{2}$ composites for phenol photodegradation. J. Environ. Chem. Eng. 2018, 6, 1601-1612. [CrossRef]

60. Zhang, Y.; Park, M.; Kim, H.; Park, S. In-situ synthesis of graphene oxide/BiOCl heterostructured nanofibers for visible-light photocatalytic investigation. J. Alloy. Compd. 2016, 686, 106-114. [CrossRef]

61. Zhang, J.; Zhang, L.; Shen, X.; Xu, P.; Liu, J. Synthesis of BiOBr/WO 3 p-n heterojunctions with enhanced visible light photocatalytic activity. CrystEngComm 2016, 18, 3856-3865. [CrossRef]

62. Feng, Y.; Liu, C.; Chen, J.; Che, H.; Xiao, L.; Gu, W.; Shi, W. Facile synthesis of BiOI/CdWO 4 p-n junctions: Enhanced photocatalytic activities and photoelectrochemistry. RSC Adv. 2016, 6, 38290-38299. [CrossRef]

63. Lei, L.; Jin, H.; Zhang, Q.; Xu, J.; Gao, D.; Fu, Z. A novel enhanced visible-light-driven photocatalyst via hybridization of nanosized $\mathrm{BiOCl}$ and graphitic $\mathrm{C}_{3} \mathrm{~N}_{4}$. Dalt. Trans. 2015, 44, 795-803. [CrossRef] [PubMed]

64. Ye, L.; Liu, X.; Zhao, Q.; Xie, H.; Zan, L. Dramatic visible light photocatalytic activity of MnOx-BiOI heterogeneous photocatalysts and the selectivity of the cocatalyst. J. Mater. Chem. A 2013, 1, 8978. [CrossRef]

65. Fan, W.-Q.; Yu, X.-Q.; Song, S.-Y.; Bai, H.-Y.; Zhang, C.; Yan, D.; Liu, C.-B.; Wang, Q.; Shi, W.-D. Fabrication of $\mathrm{TiO}_{2}-\mathrm{BiOCl}$ double-layer nanostructure arrays for photoelectrochemical water splitting. CrystEngComm 2014, 16, 820-825. [CrossRef] 
66. Ferreira, V.C.; Neves, M.C.; Hillman, A.R.; Monteiro, O.C. Novel one-pot synthesis and sensitisation of new $\mathrm{BiOCl}-\mathrm{Bi}_{2} \mathrm{~S}_{3}$ nanostructures from DES medium displaying high photocatalytic activity. RSC Adv. 2016, 6, 77329-77339. [CrossRef]

67. He, Z.; Shi, Y.; Gao, C.; Wen, L.; Chen, J.; Song, S. BiOCl/BiVO 4 p-n Heterojunction with Enhanced Photocatalytic Activity under Visible-Light Irradiation. J. Phys. Chem. C 2014, 118, 389-398. [CrossRef]

68. Di, J.; Xia, J.; Li, H.; Guo, S.; Dai, S. Bismuth oxyhalide layered materials for energy and environmental applications. Nano Energy 2017, 41, 172-192. [CrossRef]

69. Yang, Y.; Zhang, C.; Lai, C.; Zeng, G.; Huang, D.; Cheng, M.; Wang, J.; Chen, F.; Zhou, C.; Xiong, W. BiOX (X $=\mathrm{Cl}, \mathrm{Br}, \mathrm{I})$ photocatalytic nanomaterials: Applications for fuels and environmental management. Adv. Colloid Interface Sci. 2018, 254, 76-93. [CrossRef]

70. Kelly, A.W.; Nicholas, A.; Ahern, J.C.; Chan, B.; Patterson, H.H.; Pike, R.D. Alkali metal bismuth(III) chloride double salts. J. Alloy. Compd. 2016, 670, 337-345. [CrossRef]

71. Wang, G.; Luo, X.; Huang, Y.; Kuang, A.; Yuan, H.; Chen, H. BiOX/BiOY (X, Y = F, Cl, Br, I) superlattices for visible light photocatalysis applications. RSC Adv. 2016, 6, 91508-91516. [CrossRef]

72. Song, J.; Wang, B.; Guo, X.; Wang, R.; Dong, Z. Hierarchical nanostructured 3D flowerlike BiOX particles with excellent visible-light photocatalytic activity. J. Nanoparticle Res. 2016, 18, 1-11. [CrossRef]

73. Liu, Y.; Xu, J.; Wang, L.; Zhang, H.; Xu, P.; Duan, X.; Sun, H.; Wang, S. Three-Dimensional BiOI/BiOX (X = Cl or Br) Nanohybrids for Enhanced Visible-Light Photocatalytic Activity. Nanomaterials 2017, 7, 64. [CrossRef]

74. Cui, P.; Wang, J.; Wang, Z.; Chen, J.; Xing, X.; Wang, L.; Yu, R. Bismuth oxychloride hollow microspheres with high visible light photocatalytic activity. Nano Res. 2016, 9, 593-601. [CrossRef]

75. Sfaelou, S.; Raptis, D.; Dracopoulos, V.; Lianos, P. BiOI solar cells. RSC Adv. 2015, 5, 95813-95816. [CrossRef]

76. Jin, J.; Wang, Y.; He, T. Preparation of thickness-tunable BiOCl nanosheets with high photocatalytic activity for photoreduction of $\mathrm{CO}_{2}$. RSC Adv. 2015, 5, 100244-100250. [CrossRef]

77. Li, H.; Shang, J.; Shi, J.; Zhao, K.; Zhang, L. Facet-dependent solar ammonia synthesis of BiOCl nanosheets via a proton-assisted electron transfer pathway. Nanoscale 2016, 8, 1986-1993. [CrossRef] [PubMed]

78. Li, H.; Shang, J.; Ai, Z.; Zhang, L. Efficient visible light nitrogen fixation with BiOBr nanosheets of oxygen vacancies on the exposed \{001\} Facets. J. Am. Chem. Soc. 2015, 137, 6393-6399. [CrossRef] [PubMed]

79. Cheng, H.; Huang, B.; Wang, P.; Wang, Z.; Lou, Z.; Wang, J.; Qin, X.; Zhang, X.; Dai, Y. In situ ion exchange synthesis of the novel $\mathrm{Ag} / \mathrm{AgBr} / \mathrm{BiOBr}$ hybrid with highly efficient decontamination of pollutants. Chem. Commun. 2011, 47, 7054-7056. [CrossRef]

80. Dong, F.; Xiong, T.; Yan, S.; Wang, H.; Sun, Y.; Zhang, Y.; Huang, H.; Wu, Z. Facets and defects cooperatively promote visible light plasmonic photocatalysis with Bi nanowires@BiOCl nanosheets. J. Catal. 2016, 344, 401-410. [CrossRef]

81. Ai, Z.; Ho, W.; Lee, S.; Zhang, L. Efficient photocatalytic removal of NO in indoor air with hierarchical bismuth oxybromide nanoplate microspheres under visible light. Environ. Sci. Technol. 2009, 43, 4143-4150. [CrossRef]

82. Huang, C.; Hu, J.; Cong, S.; Zhao, Z.; Qiu, X. Hierarchical BiOCl microflowers with improved visible-light-driven photocatalytic activity by Fe(III) modification. Appl. Catal. B 2015, 174-175, 105-112. [CrossRef]

83. Dong, G.; Ho, W.; Zhang, L. Photocatalytic NO removal on BiOI surface: The change from nonselective oxidation to selective oxidation. Appl. Catal. B 2015, 168-169, 490-496. [CrossRef]

84. Dawody, J.; Skoglundh, M.; Fridell, E. The effect of metal oxide additives $\left(\mathrm{WO}_{3}, \mathrm{MoO}_{3}, \mathrm{~V}_{2} \mathrm{O}_{5}, \mathrm{Ga}_{2} \mathrm{O}_{3}\right)$ on the oxidation of $\mathrm{NO}$ and $\mathrm{SO}_{2}$ over $\mathrm{Pt} / \mathrm{Al}_{2} \mathrm{O}_{3}$ and $\mathrm{Pt} / \mathrm{BaO} / \mathrm{Al}_{2} \mathrm{O}_{3}$ catalysts. J. Mol. Catal. A Chem. 2004, 209, 215-225. [CrossRef]

85. Qamar, M.; Yamani, Z.H. Bismuth oxychloride-mediated and laser-induced efficient reduction of $\mathrm{Cr}(\mathrm{VI})$ in aqueous suspensions. Appl. Catal. A 2012, 439-440, 187-191. [CrossRef]

86. Xu, H.; Wu, Z.; Ding, M.; Gao, X. Microwave-assisted synthesis of flower-like BN/BiOCl composites for photocatalytic $\mathrm{Cr}(\mathrm{VI})$ reduction upon visible-light irradiation. Mater. Des. 2017, 114, 129-138. [CrossRef]

87. Li, G.; Qin, F.; Yang, H.; Lu, Z.; Sun, H.; Chen, R. Facile microwave synthesis of 3D flowerlike BiOBr nanostructures and their excellent CrVIremoval capacity. Eur. J. Inorg. Chem. 2012, 2508-2513. [CrossRef]

88. Li, G.; Qin, F.; Wang, R.; Xiao, S.; Sun, H.; Chen, R. Journal of Colloid and Interface Science BiOX (X $=\mathrm{Cl}, \mathrm{Br}$, I) nanostructures: Mannitol-mediated microwave synthesis, visible light photocatalytic performance, and $\mathrm{Cr}$ (VI) removal capacity. J. Colloid Interface Sci. 2013, 409, 43-51. [CrossRef] 
89. Shang, J.; Hao, W.; Lv, X.; Wang, T.; Wang, X.; Du, Y.; Dou, S.; Xie, T.; Wang, D.; Wang, J. Bismuth oxybromide with reasonable photocatalytic reduction activity under visible light. ACS Catal. 2014, 4, 954-961. [CrossRef]

90. Bai, Y.; Ye, L.; Chen, T.; Wang, P.; Wang, L.; Shi, X.; Wong, P.K. Synthesis of hierarchical bismuth-rich $\mathrm{Bi}_{4} \mathrm{O}_{5} \mathrm{Br}_{\mathrm{x}} \mathrm{I}_{2-\mathrm{x}}$ solid solutions for enhanced photocatalytic activities of $\mathrm{CO}_{2}$ conversion and $\mathrm{Cr}(\mathrm{VI})$ reduction under visible light. Appl. Catal. B 2017, 203, 633-640. [CrossRef]

91. Ye, L.; Su, Y.; Jin, X.; Xie, H.; Zhang, C. Recent advances in BiOX (X = Cl, Br and I) photocatalysts: Synthesis, modification, facet effects and mechanisms. Environ. Sci-Nano 2014, 1, 90-112. [CrossRef]

92. Di, J.; Xia, J.; Ji, M.; Yin, S.; Li, H.; Xu, H.; Zhang, Q.; Li, H. Controllable synthesis of $\mathrm{Bi}_{4} \mathrm{O}_{5} \mathrm{Br}_{2}$ ultrathin nanosheets for photocatalytic removal of ciprofloxacin and mechanism insight. J. Mater. Chem. A 2015, 3, 15108-15118. [CrossRef]

93. Di, J.; Xia, J.; Yin, S.; Xu, H.; Xu, L.; Xu, Y.; He, M.; Li, H. Preparation of sphere-like g-C $\mathrm{N}_{4} / \mathrm{BiOI}$ photocatalysts via a reactable ionic liquid for visible-light-driven photocatalytic degradation of pollutants. J. Mater. Chem. A 2014, 2, 5340-5351. [CrossRef]

94. Hao, R.; Xiao, X.; Zuo, X.; Nan, J.; Zhang, W. Efficient adsorption and visible-light photocatalytic degradation of tetracycline hydrochloride using mesoporous BiOI microspheres. J. Hazard. Mater. 2012, 209-210, 137-145. [CrossRef] [PubMed]

95. Di, J.; Xia, J.; Ji, M.; Wang, B.; Yin, S.; Zhang, Q.; Chen, Z.; Li, H. Advanced photocatalytic performance of graphene-like $\mathrm{BN}$ modified $\mathrm{BiOBr}$ flower-like materials for the removal of pollutants and mechanism insight. Appl. Catal. B 2016, 183, 254-262. [CrossRef]

96. Chen, F.; Yang, Q.; Sun, J.; Yao, F.; Wang, S.; Wang, Y.; Wang, X.; Li, X.; Niu, C.; Wang, D.; et al. Enhanced Photocatalytic Degradation of Tetracycline by $\mathrm{AgI} / \mathrm{BiVO}_{4}$ Heterojunction under Visible-Light Irradiation: Mineralization Efficiency and Mechanism. ACS Appl. Mater. Interfaces 2016, 8, 32887-32900. [CrossRef] [PubMed]

97. Gao, S.; Guo, C.; Lv, J.; Wang, Q.; Zhang, Y.; Hou, S.; Gao, J.; Xu, J. A novel 3D hollow magnetic $\mathrm{Fe}_{3} \mathrm{O}_{4} / \mathrm{BiOI}$ heterojunction with enhanced photocatalytic performance for bisphenol A degradation. Chem. Eng. J. 2017, 307, 1055-1065. [CrossRef]

98. Burkhardt-holm, P. Linking Water Quality to Human Health and Environment: The Fate of Micropollutants; Institute of Water Policy National University: Singapore, 2011.

99. Thorpe, K.L.; Cummings, R.I.; Hutchinson, T.H.; Scholze, M.; Brighty, G.; Sumpter, J.P.; Tyler, C.R. Relative potencies and combination effects of steroidal estrogens in fish. Environ. Sci. Technol. 2003, 37, 1142. [CrossRef]

100. Yan, Z.; Lu, G.; Liu, J.; Jin, S.; Bay, Z. An integrated assessment of estrogenic contamination and feminization risk in fish in Taihu Lake, China. Ecotoxicol. Environ. Saf. 2012, 84, 334-340. [CrossRef]

101. Schwindt, A.R.; Winkelman, D.L.; Keteles, K.; Murphy, M.; Vajda, A.M. An environmental oestrogen disrupts fish population dynamics through direct and transgenerational effects on survival and fecundity. J. Appl. Ecol. 2014, 51, 582-591. [CrossRef]

102. Chen, Q.; Shi, J.; Liu, X.; Wu, W.; Liu, B.; Zhang, H. Simulation of estrogen transport and behavior in laboratory soil columns using a cellular automata model. J. Contam. Hydrol. 2013, 146, 51-62. [CrossRef]

103. Langston, W.J.; Burt, G.R.; Chesman, B.S.; Vane, C.H. Partitioning, bioavailability and effects of oestrogens and xeno-oestrogens in the aquatic environment. J. Mar. Biol. Assoc. 2005, 85, 1-31. [CrossRef]

104. Hamid, H.; Eskicioglu, C. Fate of estrogenic hormones in wastewater and sludge treatment: A review of properties and analytical detection techniques in sludge matrix. Water Res. 2012, 46, 5813-58133. [CrossRef] [PubMed]

105. Liu, X.; Shi, J.; Zhang, H.; Zhan, X.; Shen, G.; Hu, S. Estimating Estrogen Release and Load from Humans and Livestock in Shanghai, China. J. Environ. Qual. 2014, 43, 568-577. [CrossRef] [PubMed]

106. Hannah, R.; D’Aco, V.; Anderson, P.; Buzby, M.; Caldwell, D.; Cunningham, V.; Ericson, J.; Johnson, A.; Parke, N.; Samuelian, J. Sumpter Exposure assessment of $17 \alpha$-ethinylestradiol in surface waters of the United States and Europe. Environ. Toxicol. Chem. 2009, 28, 2725. [CrossRef] [PubMed]

107. Filby, A.L.; Thorpe, K.L.; Tyler, C.R. Multiple molecular effect pathways of an environmental oestrogen in fish. J. Mol. Endocrinol. 2006, 37, 121-134. [CrossRef] [PubMed]

108. Kumar, A.; Xagoraraki, I. Pharmaceuticals, personal care products and endocrine-disrupting chemicals in U.S. surface and finished drinking waters: A proposed ranking system. Sci. Total Environ. 2010, 408, 5972-5989. [CrossRef] [PubMed] 
109. Yin, G.-G.; Kookana, R.S.; Ru, Y.-J. Occurrence and fate of hormone steroids in the environmen. Environ. Int. 2002, 28, 545-551. [PubMed]

110. Hallgren, P.; Nicolle, A.; Hansson, L.-A.; Brönmark, C.; Nikoleris, L.; Hyder, M.; Persson, A. Synthetic estrogen directly affects fish biomass and may indirectly disrupt aquatic food webs. Environ. Toxicol. Chem. 2014, 33, 930-936. [CrossRef]

111. Ferguson, E.M.; Allinson, M.; Allinson, G.; Swearer, S.E.; Hassell, K.L.; Bay, P.P. Fluctuations in natural and synthetic estrogen concentrations in a tidal estuary in south-eastern Australia. Water Res. 2012, 47, 1604-1615. [CrossRef]

112. Keller, E.; Kramer, V.Z. A Strong Deviation from Vegard's Rule: X-ray Powder Investigations of the Three Quasi-Binary Phase Systems BiOX-BiOY (X, Y = Cl, Br, I). Zeitschrift für Naturforschung B 2005, 60, 1255-1263. [CrossRef]

113. Chang, X.; Huang, J.; Cheng, C.; Sui, Q.; Sha, W.; Ji, G.; Deng, S.; Yu, G. BiOX (X = Cl, Br, I) photocatalysts prepared using $\mathrm{NaBiO}_{3}$ as the Bi source: Characterization and catalytic performance. Catal. Commun. 2010, 11, 460-464. [CrossRef]

114. Deng, Z.; Tang, F.; Muscat, A.J. Strong blue photoluminescence from single-crystalline bismuth oxychloride nanoplates. Nanotechnology 2008, 19, 295705. [CrossRef]

115. Chang, X.; Huang, J.; Tan, Q.; Wang, M.; Ji, G.; Deng, S.; Yu, G. Photocatalytic degradation of PCP-Na over BiOI nanosheets under simulated sunlight irradiation. Catal. Commun. 2009, 10, 1957-1961. [CrossRef]

116. Meng, S.; Bi, Y.; Yan, T.; Zhang, Y.; Wu, T.; Shao, Y.; Wei, D.; Du, B. Room-temperature fabrication of bismuth oxybromide/oxyiodide photocatalyst and efficient degradation of phenolic pollutants under visible light. J. Hazard. Mater. 2018, 358, 20-32. [CrossRef] [PubMed]

117. Lam, S.; Sin, J.; Abdullah, A.Z.; Mohamed, A.R. Photocatalytic degradation of resorcinol, an endocrine disrupter, by TiO 2 and ZnO suspensions. Environ. Technol. 2013, 34, 1097-1106. [CrossRef]

118. Arthur, R.B.; Bonin, J.L.; Ardill, L.P.; Rourk, E.J.; Patterson, H.H.; Stemmler, E.A. Photocatalytic degradation of ibuprofen over BiOCl nanosheets with identification of intermediates. J. Hazard. Mater. 2018, 358, 1-9. [CrossRef] [PubMed]

119. Li, J.; Sun, S.; Chen, R.; Zhang, T.; Ren, B.; Dionysiou, D.D.; Wu, Z.; Liu, X.; Ye, M. Adsorption behavior and mechanism of ibuprofen onto BiOCl microspheres with exposed $\{001\}$ facets. Environ. Sci. Pollut. Res. 2017, 24, 9556-9565. [CrossRef]

120. Li, J.; Sun, S.; Qian, C.; He, L.; Chen, K.K.; Zhang, T.; Chen, Z.; Ye, M. The role of adsorption in photocatalytic degradation of ibuprofen under visible light irradiation by BiOBr microspheres. Chem. Eng. J. 2016, 297, 139-147. [CrossRef]

121. Gamarra, J.S.; Godoi, A.F.L.; de Vasconcelos, E.C.; de Souza, K.M.T.; Ribas de Oliveira, C.M. Environmental Risk Assessment (ERA) of diclofenac and ibuprofen: A public health perspective. Chemosphere 2015, 120, 462-469. [CrossRef]

122. Castell, J.V.; Gomez, L.M.J.; Miranda, M.A.; Morera, I.M. Photolytic Degradation of Ibuprofen. Toxicity of the Isolated Photoproducts on Fibroblasts and Erythrocytes. Photochem. Photobiol. 1987, 46, 991-996. [CrossRef]

123. Da Silva, J.C.C.; Teodoro, J.A.R.; Afonso, R.J.D.C.F.; Aquino, S.F.; Augusti, R. Photolysis and photocatalysis of ibuprofen in aqueous medium: Characterization of by-products via liquid chromatography coupled to high-resolution mass spectrometry and assessment of their toxicities against Artemia Salina. J. Mass Spectrom. 2014, 49, 145-153. [CrossRef] [PubMed]

124. Jacobs, L.E.; Fimmen, R.L.; Chin, Y.-P.; Mash, H.E.; Weavers, L.K. Fulvic acid mediated photolysis of ibuprofen in water. Water Res. 2011, 45, 4449-4458. [CrossRef] [PubMed]

125. Jakimska, A.; Śliwka-Kaszyńska, M.; Reszczyńska, J.; Namieśnik, J.; Kot-Wasik, A. Elucidation of transformation pathway of ketoprofen, ibuprofen, and furosemide in surface water and their occurrence in the aqueous environment using UHPLC-QTOF-MS. Anal. Bioanal. Chem. 2014, 406, 3667-3680. [CrossRef] [PubMed]

126. Li, F.H.; Yao, K.; Lv, W.Y.; Liu, G.G.; Chen, P.; Huang, H.P.; Kang, Y.P. Photodegradation of Ibuprofen Under UV-Vis Irradiation: Mechanism and Toxicity of Photolysis Products. Bull. Environ. Contam. Toxicol. 2015, 94, 479-483. [CrossRef] [PubMed]

127. Ruggeri, G.; Ghigo, G.; Maurino, V.; Minero, C.; Vione, D. Photochemical transformation of ibuprofen into harmful 4-isobutylacetophenone: Pathways, kinetics, and significance for surface waters. Water Res. 2013, 47, 6109-6121. [CrossRef] [PubMed] 
128. Szabó, R.K.; Megyeri, C.; Illés, E.; Gajda-Schrantz, K.; Mazellier, P.; Dombi, A. Phototransformation of ibuprofen and ketoprofen in aqueous solutions. Chemosphere 2011, 84, 1658-1663. [CrossRef] [PubMed]

129. Achilleos, A.; Hapeshi, E.; Xekoukoulotakis, N.P.; Mantzavinos, D.; Fatta-Kassinos, D. UV-A and solar photodegradation of ibuprofen and carbamazepine catalyzed by $\mathrm{TiO}_{2}$. Sep. Sci. Technol. 2010, 45, 1564-1570. [CrossRef]

130. Braz, F.S.; Silva, M.R.A.; Silva, F.S.; Andrade, S.J.; Fonseca, A.L.; Kondo, M.M. Photocatalytic Degradation of Ibuprofen Using $\mathrm{TiO}_{2}$ and Ecotoxicological Assessment of Degradation Intermediates against Daphnia similis. J. Environ. Prot. 2014, 5, 620-626. [CrossRef]

131. Choina, J.; Kosslick, H.; Fischer, C.; Flechsig, G.-U.; Frunza, L.; Schulz, A. Photocatalytic decomposition of pharmaceutical ibuprofen pollutions in water over titania catalyst. Appl. Catal. B 2013, 129, 589-598. [CrossRef]

132. Mendez-Arriaga, F.; Torres-Palma, R.A.; Petrier, C.; Esplugas, S.; Gimenez, J.; Pulgarin, C. Ultrasonic treatment of water contaminated with ibuprofen. Water Res. 2008, 42, 4243-4248. [CrossRef]

133. Michael, I.; Achilleos, A.; Lambropoulou, D.; Torrens, V.O.; Pérez, S.; Petrović, M.; Barceló, D.; Fatta-Kassinos, D. Proposed transformation pathway and evolution profile of diclofenac and ibuprofen transformation products during (sono)photocatalysis. Appl. Catal. B 2014, 147, 1015-1027. [CrossRef]

134. Illés, E.; Takács, E.; Dombi, A.; Gajda-Schrantz, K.; Rácz, G.; Gonter, K.; Wojnárovits, L. Hydroxyl radical induced degradation of ibuprofen. Sci. Total Environ. 2013, 447, 286-292. [CrossRef] [PubMed]

135. Tobergte, D.R.; Curtis, S. Environmentally Benign Photocatalysts Applications of Titanium Oxide-Based Materials; Springer: Berlin/Heidelberg, Germany, 2010; ISBN 9788578110796.

136. Song, Z.; Dong, X.; Wang, N.; Zhu, L.; Luo, Z.; Fang, J.; Xiong, C. Efficient photocatalytic defluorination of perfluorooctanoic acid over $\mathrm{BiOCl}$ nanosheets via a hole direct oxidation mechanism. Chem. Eng. J. 2017, 317, 925-934. [CrossRef]

137. Moyet, M.A.; Arthur, R.B.; Lueders, E.E.; Breeding, W.P.; Patterson, H.H. The role of Copper (II) ions in $\mathrm{Cu}-\mathrm{BiOCl}$ for Use in the Photocatalytic Degradation of Atrazine. J. Environ. Chem. Eng. 2018, 6, 5595-5601. [CrossRef]

138. Granados-Oliveros, G.; Páez-Mozo, E.A.; Ortega, F.M.; Ferronato, C.; Chovelon, J.M. Degradation of atrazine using metalloporphyrins supported on $\mathrm{TiO}_{2}$ under visible light irradiation. Appl. Catal. B 2009, 89, 448-454. [CrossRef]

139. Libanori, R.; Giraldi, T.R.; Longo, E.; Leite, E.R.; Ribeiro, C. Effect of $\mathrm{TiO}_{2}$ surface modification in Rhodamine B photodegradation. J. Sol-Gel Sci. Technol. 2009, 49, 95-100. [CrossRef]

140. Wen, X.J.; Niu, C.G.; Guo, H.; Zhang, L.; Liang, C.; Zeng, G.M. Photocatalytic degradation of levofloxacin by ternary $\mathrm{Ag}_{2} \mathrm{CO}_{3} / \mathrm{CeO}_{2} / \mathrm{AgBr}$ photocatalyst under visible-light irradiation: Degradation pathways, mineralization ability, and an accelerated interfacial charge transfer process study. J. Catal. 2018, 358, 211-223. [CrossRef]

141. Sudrajat, H.; Sujaridworakun, P. Insights into structural properties of $\mathrm{Cu}$ species loaded on $\mathrm{Bi}_{2} \mathrm{O}_{3}$ hierarchical structures for highly enhanced photocatalysis. J. Catal. 2017, 352, 394-400. [CrossRef]

(c) 2018 by the authors. Licensee MDPI, Basel, Switzerland. This article is an open access article distributed under the terms and conditions of the Creative Commons Attribution (CC BY) license (http:/ / creativecommons.org/licenses/by/4.0/). 